\title{
Industry 4.0: a bibliometric review of its managerial intellectual structure and potential evolution in the service industries
}

Article

Accepted Version

Creative Commons: Attribution-Noncommercial-No Derivative Works 4.0

Mariani, M. and Borghi, M. ORCID: https://orcid.org/00000002-4150-1595 (2019) Industry 4.0: a bibliometric review of its managerial intellectual structure and potential evolution in the service industries. Technological Forecasting and Social Change, 149. 119752. ISSN 0040-1625 doi:

https://doi.org/10.1016/j.techfore.2019.119752 Available at https://centaur.reading.ac.uk/86232/

It is advisable to refer to the publisher's version if you intend to cite from the work. See Guidance on citing.

To link to this article DOI: http://dx.doi.org/10.1016/j.techfore.2019.119752

Publisher: Elsevier

All outputs in CentAUR are protected by Intellectual Property Rights law, including copyright law. Copyright and IPR is retained by the creators or other copyright holders. Terms and conditions for use of this material are defined in the End User Agreement. 


\section{CentAUR}

Central Archive at the University of Reading

Reading's research outputs online 


\title{
Industry 4.0: \\ A bibliometric review of its managerial intellectual structure and potential evolution in the service industries
}

\begin{abstract}
The "industry 4.0" phenomenon is expected to influence almost every aspect of business value chains, and hence it has been increasingly analyzed by management scholars. However, the overarching intellectual structure emerging from this new stream of literature has not yet been synthesized in a framework nor critically discussed. Furthermore, despite being part of the rhetoric in several recent industrial governmental plans, industry 4.0 in service sectors has not been systematically reviewed to date. By leveraging a systematic quantitative literature review, a data-driven approach and a quantitative methodology-embedding both bibliographic coupling and network analysis techniques - this study provides a clear visualization of the emerging intellectual structure of industry 4.0 in management studies. We also develop a framework based on the most recurrent themes emerging from the results of bibliometric and network analyses - the latter could be used by management scholars to understand studies surrounding industry 4.0. As service businesses can create and capture value generated through the $4^{\text {th }}$ Industrial Revolution as well as manufacturing firms, we suggest that scholarly attention should also be directed toward the service industries and provide a research agenda.
\end{abstract}

Keywords: Industry 4.0; Fourth Industrial Revolution; Services; Systematic Quantitative Literature Review; Bibliographical Coupling; Social Network Analysis 


\section{Introduction}

The contemporary society is witnessing the emergence of an uncontrollable innovation wave underpinned by technological development in a wide range of fields. In its broadest connotation, the phenomenon has been labelled by several scholars and practitioners as "the fourth industrial revolution" (European Commission, 2016b; Kang et al., 2016; Liao et al., 2017; Schwab, 2016; Skilton and Hovsepian, 2017). Specifically, it is a socio-technical process affecting the physical, digital, and biological domains, based on the innovative and effective exploitation of a wide range of new and emerging prevalently digital technologies through their fusion and interaction (Schwab, 2016). Even though part of the practitioners' community considered this process as a natural evolution of the third industrial revolution (Drath and Horch, 2014; O'Halloran and Kvochko, 2015; Syska and Liévre, 2016), undeniably, digital transformation is disrupting entire sectors and industries with the emergence and development of new business models relying significantly on digital technologies (Geissbauer et al., 2016; Sung, 2018). Furthermore, this industrial shift has been accompanied by an academic projection of its outcomes (Gilchrist, 2016).

The German government's first announcement of its plan "Industrie 4.0," at the Hannover Fair in 2011, to safeguard the long-term competitiveness of its national manufacturing industry was the watershed event that triggered this "revolution" (Hermann et al., 2016). The fourth industrial revolution was initially labelled "Industrie 4.0" and it was confined to the manufacturing sector (Skilton and Hovsepian, 2017). The original definition reads, "In essence, Industrie 4.0 will involve the technical integration of cyber physical systems (CPSs) into manufacturing and logistics and the use of the Internet of Things and Services in industrial processes” (Kagermann et al., 2013: 14). The outcomes of these processes would have "implications for value creation, business models, downstream services, and work organization.” (Kagermann et al., 2013: 14). In the light of a critical reading of the aforementioned statement by Kagermann et al. (2013), and based on a lack of studies exploring the managerial impact of the industry 4.0 phenomenon, this manuscript aims to derive and elaborate the intellectual structure of the emerging research streams related to industry 4.0 in the wider social sciences, by reviewing extant literature in a data-driven fashion. Besides, by following the evolution of the phenomenon at the governmental level, we investigated if and to what extent services (and service industries) have been addressed by management scholars from the perspective of industry 4.0. The rhetoric, policies, and practices of major national and supranational governments are increasingly emphasizing the relevance of services in the form of a "Smart Service World" (German Federal Ministry, 2017) and "Service 4.0" (European Commission, 2016a; Rehse et al., 2016). This suggests that, at least from a policymaking perspective, and apparently from an institutional entrepreneurship one, there is an increasing emphasis on the transition of the ongoing 
4th industrial revolution from the manufacturing to the service industries domain. Essentially, this study also highlights the potential evolution of the industry 4.0 literature in the field of service industries that contribute to the highest share of GDP in most of the advanced economies (Buckley and Majumdar, 2018).

The study is distinctive for several reasons. First, to the best of our knowledge, this study is the first attempt to examine industry 4.0 in the services domain. Second, part of the novelty is also related to the methodological perspective of the study. The study leverages on a data-driven approach, which is innovative and cannot be found in existing reviews dealing with the industry 4.0 phenomenon within social sciences and management studies (Piccarozzi et al., 2018; Schneider, 2018). Specifically, we adopt a bibliometric technique, that is, bibliographical coupling, to identify emerging research lines and streams in the analyzed literature (Zupic and Čater, 2015). Furthermore, we conduct a more granular analysis by leveraging a wider set of keywords. We also provide a clear visualization of the thematic clusters of the literature by applying a community discovery algorithm to the results of the bibliometric technique. Third, to improve the understanding of the topics dealt with by management and social sciences scholars regarding the $4^{\text {th }}$ Industrial revolution, we build a framework that presents the most substantial findings from the network structure.

The manuscript is organized as follows. Section 2 provides an in-depth overview of the term Industrie 4.0 and its related initiatives; it also highlights the research questions addressed by the study. Section 3 illustrates the research design, which comprises a collection of scholarly documents and retrieval and analysis methods. The subsequent subsection includes an in-depth description of the bibliometric technique selected for the purposes of the study, namely bibliographical coupling, and social network analyses techniques. Section 4 describes the findings, at macro- and microlevels, by illustrating the sampled studies. This section also portrays each of the communities detected through the social network analysis as well as the quantitative results related to the analysis of services. Finally, section 5 elaborates and discusses the findings and offers several conclusions.

\section{Evolution of Industry 4.0}

\subsection{Industrie 4.0: Definitions}

As described by the "Industrie 4.0 Working Group" (Hermann et al., 2016; Kagermann et al., 2013), the three basic concepts underpinning the Industrie 4.0 phenomenon are: cyber physical systems (CPSs), Internet of things (IoTs), and smart factories. CPSs allow the fusion of the virtual and physical worlds and are defined as the "integrations of computation and physical processes. Embedded computers and networks monitor and control the physical processes, usually with feedback loops where physical processes affect computations and vice versa." (Lee, 2008). However, the term IoTs, 
first introduced in 1999 (Ashton, 2009), considers “'things' and 'objects', such as RFID, sensors, actuators, mobile phones, which, through unique addressing schemas, (...) interact with each other and cooperate with their neighboring 'smart' components, to reach common goals" (Giusto et al., 2010: p. v). These two concepts (i.e, CPSs and IoT) are very similar, even if they have emerged in two different epochs; however, the definition of CPSs seems to embrace a broader range of application fields (Gilchrist, 2016). Finally, the concept of Smart Factory has by combining the notions of IoTs and CPSs and by placing them inside the working space and at the core of operations. It is defined "as a factory that context-aware assists people and machines in execution of their tasks. This is achieved by systems working in background. [...] These systems accomplish their tasks based on information coming from the physical and virtual world. Information of the physical world is for instance the position or condition of a tool, in contrast to information of the virtual world like electronic documents, drawings and simulation models. [...]” (Lucke et al., 2008).

By refining the early definition of "Industrie 4.0" and by embracing its English translation, “industry 4.0," which portrays the nature of the phenomenon more as a "new paradigm," Hermann et al. (2016) define it as "a collective term for technologies and concepts of value chain organization." Specifically, considering the technical side of the phenomenon, the Boston Consulting Group (Rüßmann et al., 2015) identifies nine foundational technologies that will act as enablers of the industry 4.0 ecosystem. These nine pillars of technological advancement encompass autonomous robots, simulation, horizontal and vertical integration systems, industrial IoTs, cybersecurity, cloud, additive manufacturing, augmented reality, big data, and analytics. Despite the utilization of some of these technologies in manufacturing (Rüßmann et al., 2015), the real disruption in the production lines will likely be achieved by following Hermann et al.'s (2016) the "industry 4.0 design principles," which comprise interconnection, technical assistance, decentralized decisions, and information transparency. This process will transform the production lines from isolated and optimized cells to fully integrated data and production flows across borders (Rüßmann et al., 2015).

Embracing an institutional theory perspective (DiMaggio and Powell, 1983; Meyer and Rowan, 1977), very few scholars (Kim, 2018; Reischauer, 2018) have argued that industry 4.0 might be defined as a "meso-revolution" per se. While this perspective on the phenomenon might be interesting from an economics point of view, there are drawbacks as multiple limitations arise when applying the long wave theory (Ayres, 1990; Kondratieff, 1935; Schumpeter, 1939) to the phenomenon under analysis.

Although it is beyond the scope of the present study to discuss the identity of industry 4.0, we deploy the aforementioned insights in the discussion section to unpack the theoretical lenses that could be more suitable to further analyze the phenomenon in the context of service industries. 


\subsection{Industry 4.0: Plans and strategies}

In the realm of manufacturing, the transformation wave brought about by the "Industrie 4.0" initiative, which was launched and promoted by the German government, has prompted many other governmental and industrial plans embracing the same principles and technologies in order to enhance manufacturing performance (Ridgway et al., 2013). Almost simultaneously with the German plan, the United States of America introduced and developed the "advanced manufacturing partnership" (AMP) initiative in 2011. This initiative led to the establishment of the Advanced Manufacturing National Program Office (AMNPO) in 2012, which, in turn, is supporting the "Smart Manufacturing Innovation Institute." In Europe, France shaped and presented the plan named "La Nouvelle France Industrielle" in 2013, as an antecedent of the "Industrie du future." In the same year, the United Kingdom announced the introduction of the "Future of Manufacturing" plan to support manufacturing growth in the country over the next decades, replacing the "high-value manufacturing strategy 2012 to 2015 " previously introduced by the UK government to accelerate UK's economic growth through the use of high-value manufacturing (Liao et al., 2017). In Europe, the European Commission launched the "factories of the future (FoF)" program, a new contractual public-private partnership (PPP). In 2017, it was followed by Italy's national plan “Industria 4.0” (I4.0), supported by the Italian Ministry of Economic Development, to boost investment in new technologies and research and development and revitalize the competitiveness of Italian firms. If we look at other continents, the South Korean government was the "first mover" in Asia; in 2014, through its "innovation of manufacturing 3.0" plan, the South Korean government decided to catalyze domestic manufacturing efforts to develop innovation strategies (Kang et al., 2016). Subsequently, the same route was taken by the Chinese and Japanese governments, which led to the development and promotion of "Made in China 2025" (and the "Internet Plus") and the "Super Smart Society" plans in 2015 (Li, 2018), respectively. Finally, in 2016, the Singapore government announced its "Research, Innovation and Enterprise 2020 Plan" to propagate key principles in the advanced manufacturing and engineering domains.

Alongside governmental plans, a wide range of industrial and corporate strategies have been developed by companies involved in paving a way for the $4^{\text {th }}$ Industrial revolution. Specifically, AT\&T, Cisco, General Electric, IBM, and Intel conjointly founded the "Industrial Internet Consortium (IIC)" in 2014. The aim of this initiative was to better organize and coordinate the priorities and enabling technologies of the "Industrial Internet"; it is a term coined by General Electric with a technical basis similar to but with application domains extending beyond "Industrie 4.0" (Drath and Horch, 2014). 
Based on a triangulation of the existing definitions of the phenomenon and its related plans and strategies, we innovatively conceptualize and graphically represent the "industry 4.0 " as an umbrella term. Industry 4.0 has been supported by a range of government plans and its ecosystem is characterized by the aforementioned nine "pillars" of technologies (those proposed by Rüßmann et al., 2015). In our graphical representation, depicted in Figure 1 , the $4^{\text {th }}$ Industrial Revolution constitutes a circumlocution conceptually encompassing the industry 4.0.

Fig. 1. Authors' graphical conceptualization of the $4^{\text {th }}$ Industrial Revolution

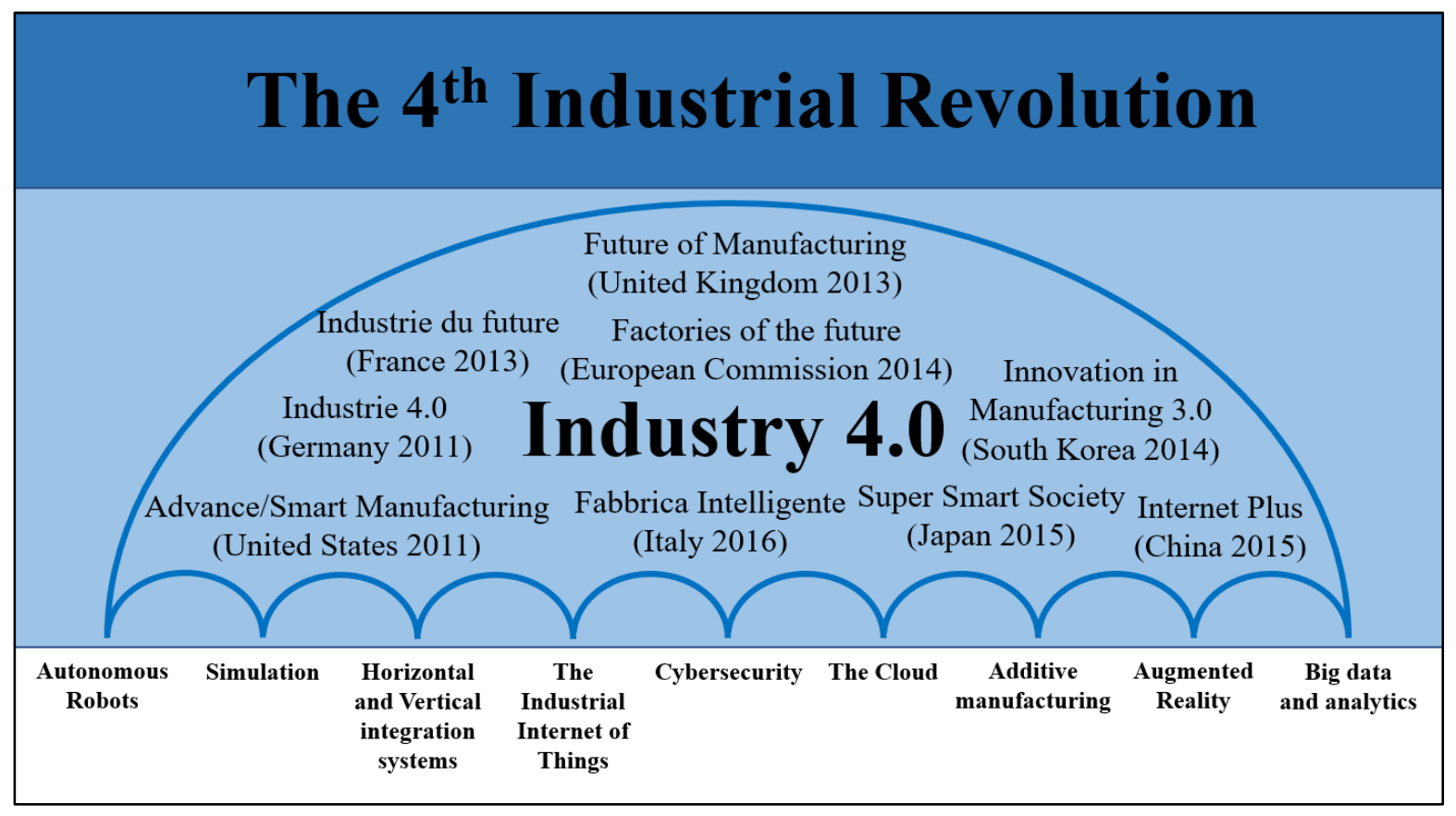

\subsection{Industry 4.0 in manufacturing and beyond: The introduction of industry 4.0 principles in the service industries domain}

Elaborated in the previous subsection, the strategies and plans concerning the adoption of the “industry 4.0" principles not only have a regional/national connotation (Geissbauer et al., 2016) but are also mainly related and confined to the manufacturing industry. However, business leaders are realizing that the phenomenon is not circumscribed only to the manufacturing sector but it can also involve the services sector (European Commission, 2016a; Rehse et al., 2016). An effective service innovation will not only benefit the service providers in terms of efficiency and effectiveness but also service customers in terms of opportunities to receive improved services comprising new and improved features and attributes (European Commission, 2016a). As stated in the opening speech of the Stakeholder conference on the Services (European Commission, 2016a), in order to deliver the value of industry 4.0 , services must also display a high level of digitalization. This implies that a modern and efficient cross-border services market should be developed. Accordingly, in the era of industry 4.0, the Boston Consulting Group (Rehse et al., 2016) coined the term Service 4.0, which is 
a broad term encompassing new disruptive technologies and concepts associated with service and support functions in organizations (European Commission, 2016a). Besides, it allows companies to share open infrastructures and deliver customized services through multiple channels in a proactive manner (Rehse et al., 2016).

Currently, governmental efforts targeting services within the industry 4.0 framework have been partially directed toward shaping policies and plans that can drive and catalyze investments for an efficient service innovation. For instance, under its high-tech strategy 2020 action plan, in 2017, the German government announced "industrie 4.0"s" successor the "future project," titled the "Smart Service World - Internet-based services for the economy" (German Federal Ministry, 2017). Related to business services, this pilot plan is generating relevant outcomes and insights for 20 selected hightech service projects, and the project aims to make Germany a leading digital provider of smart services in the future. Accordingly, the updated German government's vision of industry 4.0 builds on a new hybrid service economy, by which products and online services are integrated to develop "smart services." This pioneering initiative promoted by the German government (which is already in its second stage, named "smart services II"), indicates that business leaders digitally transforming their business may increase their focus on service industries. This also shows the pivotal role played by national governments in the launch and promotion of the industry 4.0 initiative (Kim, 2018; Reischauer, 2018) and leads to the question whether service industries will become the next application context and setting of the $4^{\text {th }}$ Industrial Revolution. Addressing this question is particularly important as industry reports suggest that the digital transformation of service industries is particularly promising as today services account for the highest share of the total GDP in most of the advanced economies and they are becoming increasingly vital to countries' economic growth (Buckley and Majumdar, 2018).

To date, a limited number of studies in the management and, especially, entrepreneurship fields have referred to the role that digital transformation might play within the service industries to create and exploit novel business opportunities, encourage business model innovation, build a sustainable competitive advantage, and improve customer engagement and satisfaction (Nambisan, 2017). Accordingly, the aim of this literature review is twofold. First, we set out to investigate the impact of the meaning and nuances of the "industry 4.0" concept, as the potential fourth industrial revolution, in the bodies of literature on management and social sciences. Second, we explore if and to what extent studies in the "industry 4.0" domain have been conducted in the service industries.

Several literature reviews have been conducted in relation to industry 4.0 (Brettel et al., 2014; Chiarello et al., 2018; Galati and Bigliardi, 2019; Liao et al., 2017; Lu, 2017; Oesterreich and 
Teuteberg, 2016; Roblek et al., 2016; Xu et al., 2018) or one of its core concepts, such as smart factory (Strozzi et al., 2017) and smart manufacturing (Kang et al., 2016; Lu and Weng, 2018). However, only the studies by Piccarozzi et al. (2018) and Schneider (2018) try to explore the managerial side of the phenomenon through a systematic literature review methodology. The former sheds light on the future managerial challenges linked to industry 4.0, using a wide range of keywords and analyzing documents published until 2016 in German and English. The latter tries to define industry 4.0 from a managerial point of view, highlighting major topics and avenues for future research by only considering the keyword "industry 4.0." However, regardless of the set of utilized search keywords and terms, to the best of our knowledge, no study assesses the intellectual structure of the emerging managerial and social science literature related to industry 4.0 relying exclusively on a data-driven approach. Moreover, to date, no study has investigated if and to what extent services examined within the industry 4.0 body of literature.

Specifically, the manuscript aims to address two research questions:

1. What is the intellectual structure of recent/emerging managerial and social science literature related to the industry 4.0 ?

2. How and to what extent are management scholars addressing the industry 4.0 phenomenon in the service industries?

\section{Research design}

Since 2011, when the German government coined the term "industry 4.0," the literature based on the related socio-economic and technological phenomenon has grown exponentially (Hermann et al., 2016; Liao et al., 2017; Schneider, 2018). In order to provide an objective overview of its impact on the managerial literature, the study adopts a systematic quantitative literature review (SQLR) method (Tranfield et al., 2003), which is largely embraced by the social science community (Mariani et al., 2018; Mura et al., 2018). A narrative literature review method could have been perceived as more subjective (Cipriani and Geddes, 2003), susceptible to difficulties in data and outcomes reproduction (Hart, 2018), and not involving an exhaustive and accurate quantitative analysis (Pickering and Byrne, 2014).

After retrieving the initial set of documents, we performed a bibliometric analysis, namely bibliographical coupling, to identify the emerging trends in the $4^{\text {th }}$ industrial revolution literature. This bibliometric method has been found to be the most suitable to map novel research streams in an emerging field (Boyack and Klavans, 2010). Subsequently, we carried out a qualitative analysis of the full text of each document to assess the role played by services in the industry 4.0 landscape. 


\subsection{Documents' collection}

The original concept of "industrie 4.0" has been embedded in many governmental and industrial plans that have introduced and/or used a novel set of specific terms and keywords to develop a compelling narrative for facilitating the $4^{\text {th }}$ industrial revolution. Interestingly, scholars trying to clarify the scope of industry 4.0 have also identified new possible synonyms of the industry 4.0 notion. Thus, in order to collect the most comprehensive set of studies dealing with this new industrial revolution (Hermann et al., 2016; Liao et al., 2017; Möller, 2016), we developed a research query encompassing a list of keywords related to the "industry 4.0" phenomenon and all its facets and nuances. Every search string was combined with the "OR" operator to create the final search string. Table 1 contained all the terms related to "industry 4.0" included in the research query, broken down by the country whose government introduced the focal plan, the organizations that coined the term, and the scholars who came up with different synonyms.

Table 1. Industry 4.0 keywords

\begin{tabular}{|l|l|}
\hline Nations & Industry 4.0 keywords \\
\hline Germany & Industrie 4.0, Industry 4.0 \\
\hline The United States of America & Smart Manufacturing, Advanced Manufacturing \\
\hline France & Industrie du future \\
\hline The United Kingdom & High value manufacturing, future of manufacturing \\
\hline European Commission & Factories of the Future, Factories 4.0 \\
\hline South Korea & Manufacturing 3.0 \\
\hline China & Made in China 2025, Internet Plus \\
\hline Japan & Super Smart Society \\
\hline Italy & Industria 4.0, Fabbrica Intelligente, Impresa 4.0 \\
\hline Organizations & Industrial Internet \\
\hline General Electric & Fourth industrial revolution, $4^{\text {th }}$ industrial revolution \\
\hline Scholars & Digital manufacturing \\
\hline Liao et al. (2017) & Integrated Industry, Smart Industry \\
\hline Möller (2016) & Smart Factory, Production 4.0 \\
\hline Hermann et al. (2016) &
\end{tabular}

The database chosen to retrieve the pertinent and focal documents is Scopus, founded and owned by the publisher Elsevier. The database is considered, alongside Web of Science, the most prominent source of academic works in the social sciences domain (Vieira and Gomes, 2009). There are three reasons behind its selection. First, systematic quantitative literature reviews and bibliometric studies in the social sciences field - and somehow also those related to research streams on industry 4.0typically leverage only on one database: either Scopus (Galati and Bigliardi, 2019) or Web of Science (Strozzi et al., 2017; Li et al., 2017), mostly due to data homogenization issues that emerge when deploying multiple different databases. Second, as scholars face a trade-off between data coverage and cleanliness, Scopus has been found to have a coverage of approximately $60 \%$ larger than WoS 
(Zhao and Strotmann, 2015), which increases over time in relation to the WoS (Mongeon and PaulHus, 2016; Waltman, 2016). Currently, Scopus indexes 70 million items and comprises more than 5,000 publishers and 22,800 serial titles. Third, while Google Scholar currently plays a key role in enabling the search for academic and scientific outputs, unlike Scopus and WoS, it does not provide any user application programming interface (API) to retrieve documents and their reference easily list in order to conduct bibliometric studies. Furthermore, Google's policy does not allow automatic downloads by using data scraping modules and often blocks automatic downloads. Hence, the vast majority of systematic quantitative literature reviews and bibliometric studies (especially in social sciences) have not used Google Scholar (Zupic and Čater, 2015). In conclusion, we opted for Scopus over WoS and Google Scholar as it allows to strike an optimal balance among the following: (i) a very good level of data coverage, (ii) convenience in data retrieval and (iii) data cleanliness. This is consistent with recent research in which, despite using more than one source, the author finds that Scopus displays the highest coverage of relevant articles in the focal field (Piccarozzi et al., 2018).

To corroborate the robustness, accuracy, and effectiveness of our choice, we searched for the same set of keywords in both Scopus and WoS and discovered that the cumulative distribution of the overall number of documents retrieved from Scopus is consistently higher than those retrieved from the WoS, confirming the higher coverage of Scopus.

We retrieved the entire set of publications related to the subject to search for one of the keywords related to the industry 4.0 in either the abstract, title, or keywords of an item in the database; without adopting any limitation criteria, the search query returned 11,716 documents.

The indexed items were broken down to 3,610 and 675 , considering the terms "industry 4.0" or "industrie 4.0" on one side and " $4^{\text {th }}$ industrial revolution" or "fourth industrial revolution" on the other side, respectively. As shown in Figure 2, there has been a rapid growth in literature related to industry 4.0, especially, in the last few years, displaying almost an exponential growth. Moreover, the graph in Figure 2 depicts a significant difference in terms of the number of items across the three categories analyzed. Particularly, the amount of publications considering the entire set of keywords related to industry 4.0 is almost twice the amount of the items retrieved by considering the terms "industry 4.0" or "industrie 4.0." For example, an US scholar may have referred to the concept of industry 4.0 in own study, through the use of the term "advanced manufacturing" (Reynolds and Uygun, 2018) introduced by the US government to illustrate and describe the same principles as those pertaining to industry 4.0. This empirical observation indicated that the initial set of keywords must be expanded to include a wider range of keywords to develop a representative sample of the initial set of documents. 
Fig. 2. Publication trend of studies surrounding the industry 4.0 phenomenon

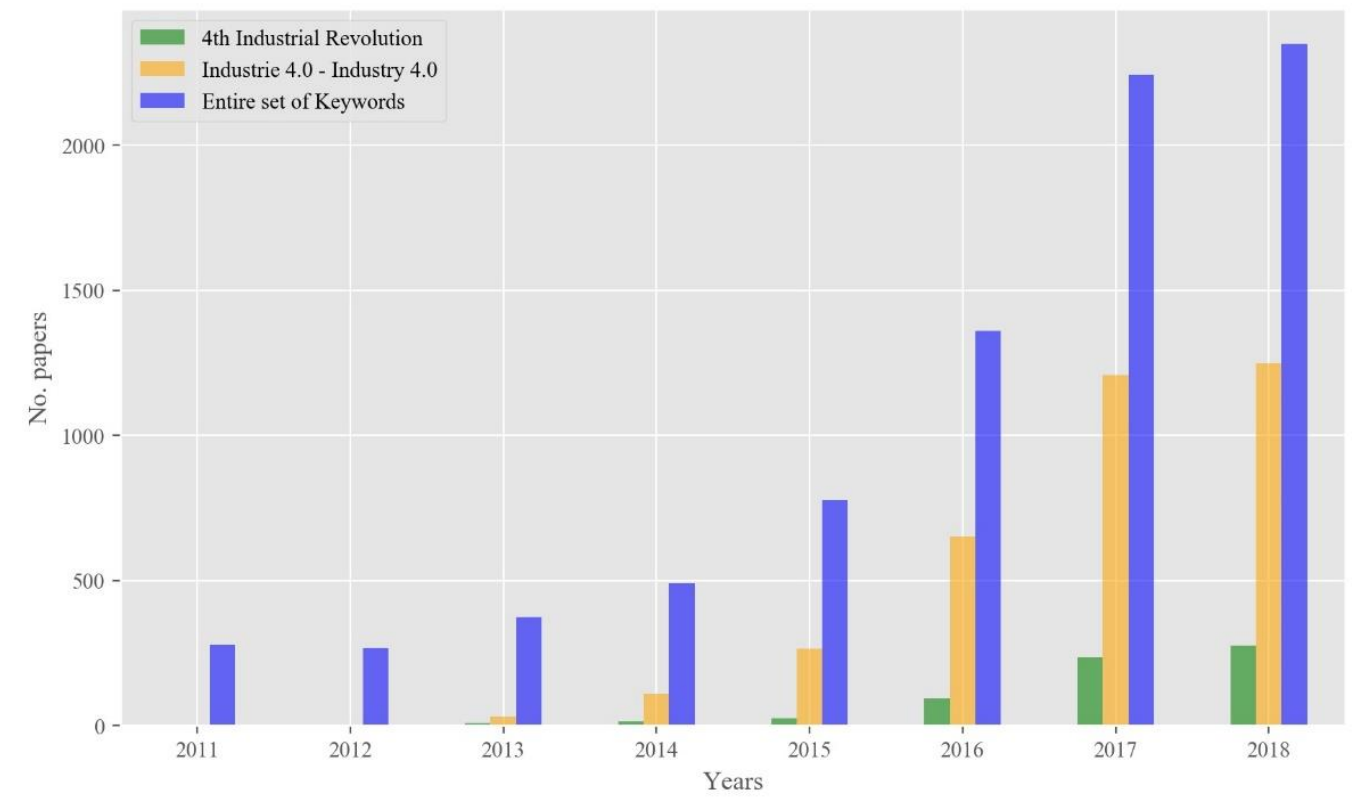

During the refinement process of the literature review, we adopted several criteria to focus on the research articles related to the objective of our study. Thus, by using search queries, we retrieved items that met the following criteria:

1. Include one of the terms in the defined set of keywords related to the industry 4.0 in either their abstract or title or related keywords.

2. Belong to one of the selected subject areas:

a. Business, Management, and Accounting

b. Decision Sciences

c. Economics, Econometrics and Finance

d. Social Sciences

3. The publication must be categorized as:
a. article
b. article in press
c. review
d. editorial

4. The document must be in English

5. The document must have been published after 2011 — when both the German and the US governments announced and launched their first governmental plan related to the $4^{\text {th }}$ industrial revolution - and must be present in the database before $1^{\text {st }}$ October 2018 when the documents were retrieved. 
Following the aforementioned criteria, the queries returned 757 documents identified as potentially eligible items for our study. This collection of documents contained 30,349 references to 25,672 different sources. Figure 3 illustrates the data retrieval process.

Fig. 3. Data retrieval process

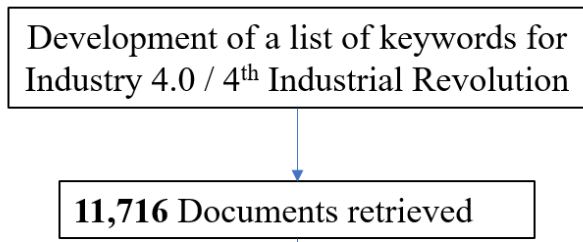

Filtering Criteria:

- Research Areas: Business, Management and Accounting; Decision Sciences; Economics, Econometrics and Finance, Social Sciences

- Catalogued as: article, article in press, review, editorial

- Language: Full-text in English

- Published online between 2011 and $1^{\text {st }}$ October 2018

$\mathbf{7 5 7}$ Documents retrieved

\subsection{Method}

Since the study aims to identify emerging streams of literature embracing the concept of industry 4.0, we analyze the studies and classify the main findings in the most objective manner; the data analysis is conducted through the use of bibliographic coupling. This bibliometric method, which can reconstruct the structural image of a scientific field, is most suitable to map out current research streams and fronts (Small, 1999; Zupic and Čater, 2015). Despite being widely neglected by managerial scholars, in relation to more mainstream methods, such as co-citation analysis, bibliographic coupling seems to have a great potential in the management domain, as emphasized by Zupic and Čater (2015) in their survey on the use of bibliometric methods in the management and organization scientific fields. Moreover, in recent years, it has been proven to be more effective and accurate than co-citation analysis in representing a research front (Boyack and Klavans, 2010).

In essence, bibliographical coupling infers the similarity between two documents as the degree of overlap of their reference lists. In other words, the number of shared references between two documents represents the measure of similarity between them (Kessler, 1963). Thus, this implies that the greater the number of shared records in the reference lists of two distinct articles, the stronger the connection between the analyzed documents. Figure 4 graphically captures the similarity mechanism underpinning the bibliographical coupling analysis. Under the scope of this bibliometric technique, the authors of the retrieved documents decide which kind of document to cite and link theirs to; as 
such, the connection captured by bibliographic coupling is guided by authors' decisions about the literature they want to cite (Zupic and Čater, 2015). Therefore, unlike co-citation, bibliometric coupling is immediately available and can include new publications that have not been cited yet, since the reference list remains static during the years. However, since citation habits change over time, conducting the analysis over a limited timeframe is considered critical to obtaining the best performance for bibliographic coupling (Glänzel and Thijs, 2011). Accordingly, as the "industry 4.0" was formally introduced in 2011 and the related literature recorded an exponential growth after 2015 (see Figure 2), we are confident that the use of bibliographical coupling would be instrumental to achieving the aim of this work effectively. Indeed, we are analyzing a recent phenomenon, whose structural image as a research stream is still emerging and being shaped in the management literature.

Fig. 4. Authors' representation of bibliographic coupling adapted from Garfield (2001) and Vogel and Güttel (2013)

Bibliographical Coupling: Document $\mathbf{A}$ and $\mathbf{B}$ are related because they both cite $\mathbf{C}$

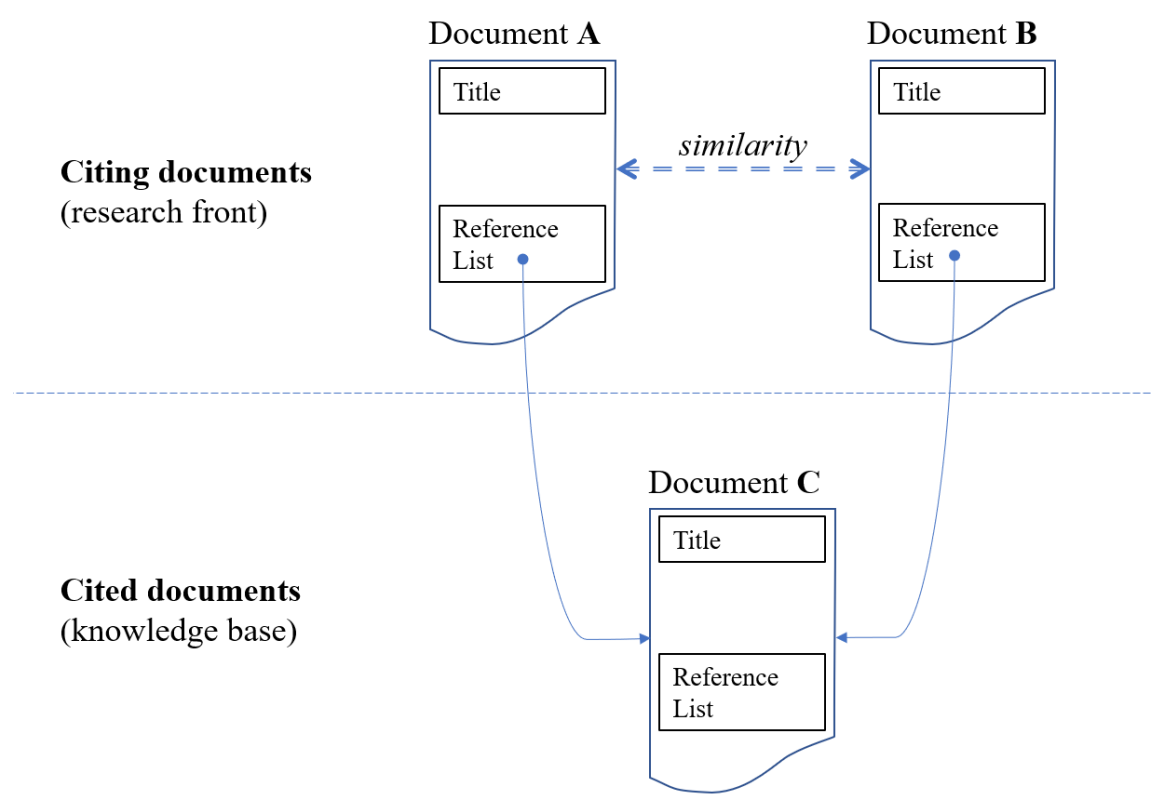

Bibliographical coupling, like other bibliometric techniques (e.g. co-citation analysis), aims to extract meaning from the reference list of each analyzed document (Kessler, 1963). Thus, a homogeneously formatted citation list is critical to performing a robust bibliographical coupling analysis leading to meaningful results. Consequently, we started our bibliometric analysis with a data cleaning phase, pre-processing the data included in the reference list of each analyzed document. At this stage of the process, like other authors (e.g., Strozzi et al., 2017), we found many inconsistencies in the citation references of the data retrieved from Scopus. For example, at a macro level, the German report which first defines industry 4.0 (Kagermann et al., 2013) was cited in 14 different ways. Furthermore, a 
close and appropriate examination of the data will show that some records did not display an exact match as one document reported the volume of the journal in which the article was published, that is, the reference included the DOI of the cited document. These issues led us to try different bibliometric software, widely used in other bibliometric studies (Zupic and Čater, 2015), such as BibExcel (Persson et al., 2009), Sitkis (Schildt and Mattsson, 2006), and SciMAT (Cobo et al., 2012), in order to reduce the noise embedded in our data. Nonetheless, these software did not produce satisfactory results; BibExcel did not feature any pre-processing capability, Sitkit was able to perform just some basic data pre-processing tasks, and SciMAT, the most difficult to use, despite its potential to conduct a scientific mapping analysis, allowed us just to export the data through the use of (undocumented) script for further analysis.

Since the landscape of bibliometric software did not offer the right flexibility, controllability, and pre-processing capabilities needed, we developed our own bibliometric modules using Python. In the first step, we crafted a module to clean the data in the reference list using string similarity techniques. First, we employed the levenshtein algorithm (the one used by SciMAT) (Levenshtein, 1966) using the Python library "python-levenshtein" (https://pypi.org/project/python-

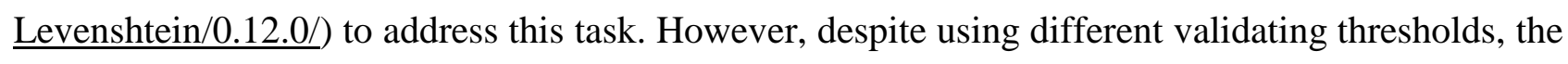
results still contained a high amount of noise. Hence, we tried a different and more complex approach using a pattern recognition algorithm introduced by Ratcliff and Obershelp in 1983 (Ratcliff and Metzener, 1998), which was implemented in the Python library "difflib" (https://docs.python.org/2/library/difflib.html). Despite the quadratic complexity of the algorithm in the worst-case scenario, which resulted in a significantly slower process than the application of the levenshtein algorithm, the results were highly satisfactory, as illustrated later in a manual check conducted by the authors. After homogenizing the contents of the reference list, we created a cooccurrence matrix, with a row for each of the studies retrieved from Scopus and a column for every unique citation, inserting a placeholder if a retrieved study had cited one of the studies in the global citation list. Multiplying this matrix for its transposed one, we obtained a similarity matrix, which included in its cell, identified by two coordinates, such as $\mathrm{x}$ and $\mathrm{y}$, the number of shared references between document $\mathrm{x}$ and $\mathrm{y}$, with $\mathrm{x}$ and $\mathrm{y}$ being two documents in the initial set of sampled studies.

To ensure robustness in the analysis previously performed with Python, the authors manually checked the number of shared documents in the reference list of 10 random articles from different publishers (45 comparisons in total). The results revealed that the similarity index found using the Ratcliff-Obershelp algorithm was exact in $42 / 45$ comparisons (93,3\% of accuracy), which outperformed the levenshtein algorithm's results that scored only the exact measure for 37/45 comparisons ( $82,2 \%$ of accuracy). Having built the foundations of our bibliographical coupling by 
creating the similarity matrix, the next step was to identify the clusters of documents related to the same research streams in the managerial literature on industry 4.0. To this end, we processed the similarity matrix through network analysis; it is considered a fresh, effective, and accurate approach toward finding subgroups in bibliometric studies (Zupic and Čarter, 2015), and it has been increasingly adopted in the latest bibliometric studies (Ma et al., 2012; Vogel and Güttel, 2013; Li et al., 2018; Mura et al., 2018) over more traditional approaches, such as multidimensional scaling or hierarchical clustering (Zupic and Čater, 2015).

We created an ad-hoc Python module to process the similarity matrix and obtain the underlying network, using the Python library Networkx (https://networkx.github.io/). Subsequently, we applied the Louvain community discovery algorithm (Blondel et al., 2008) to produce the partitions of the entire network, by exploiting the Python library "python-louvain" (https://github.com/taynaud/python-louvain). The Louvain method, developed by Blondel et al. (2008), uses a "greedy approach" to take advantage of the notion of network modularity in order to optimize the process of dividing the entire network into sub-groups (also called clusters, modules or communities). This technique has been proven to have a high level of accuracy and it can accelerate the analysis even in networks with an extremely large number of nodes (Liu et al., 2012). The algorithm operates in the following two steps: first, it assigns a different community to each node in the network; second, it iterates along the entire set of clusters, trying to assign a node to a different cluster in order to maximize the modularity of the entire network. At each iteration step, it changes the community of the node, which actually produces the greatest increase in terms of modularity (Blondel et al., 2008).

Since the Louvain algorithm assigns a community to each node in the network, the main drawback of this technique is that it requires the filtering of important items beforehand (Zupic and Čater, 2015). Thus, the authors adopted an iterative approach; they applied the selected community discovery method to a wide range of networks obtained using different coupling thresholds in order to identify the one that had the ability to ensure a complete yet parsimonious set of results (Mura et al., 2018).

Finally, to generate a crystal-clear structural image of the topic under investigation, we qualitatively and quantitatively interpreted all the clusters found using the community-discovery algorithm (Mura et al., 2018). On the one hand, we conducted an in-depth analysis of every single node of the network through its full text to discern the contents and topics of each community. On the other hand, we examined the underlying structure of each sub-group, exploiting measures widely used in complex network analysis, such as density, average degree, betweenness centrality, and shortest path length (Barabási, 2016). 
Regarding the second research question related to the extent to which management scholars referred to the $4^{\text {th }}$ industrial revolution in the service industries' domain, we qualitatively analyzed all the full texts of the documents retrieved with the Natural Language ToolKit (NLTK library) provided in Python. First, we identified all the sentences containing references to services; second, we deepened our analysis to further investigate if and how industry 4.0 scholars examined the service industries.

\section{Findings}

The findings portray the structure of the themes and technologies associated with industry 4.0 that were studied in the last few years in the management and social science research domains. First, we describe the sample of collected studies from the online database, providing an overview of the material retrieved. Subsequently, we present the findings obtained using the bibliographical coupling technique, highlighting the main streams of literature and analyzing each community detected inside the entire network. Furthermore, we propose a comprehensive framework that embeds the findings stemming from the network analysis. Finally, we conduct an in-depth analysis to determine whether the literature dealing with industry 4.0 has evolved in the service industries' domain.

\subsection{Sample description}

Industry 4.0 is a novel topic that has captured the curiosity and interest of management scholars in the last few years. As depicted in Figure 5, the trend of managerial research on the topic increased exponentially after 2015. Clearly, as illustrated in Figure 6, in the managerial domain, the most prominent journals featuring research on industry 4.0 cover "production" and, especially, “manufacturing." Indeed, "manufacturing" is the most frequently used keyword-it appeared in $27 \%$ of the sampled documents. Other outlets, such as the "Journal of Manufacturing technology Management," "Sustainability," and "Technological forecasting and social change," are increasingly publishing research on the topic. Despite having chosen four main subject areas (i.e., business, management and accounting, decision sciences, economics, econometrics and finance, and social sciences), the publications retrieved from the online database are not solely related to this narrow set. This is due to the fact that a document can belong to more than one research area. Indeed, it is interesting to notice how "engineering" and "computer science" are still associated to $20 \%$ and $10 \%$ of the retrieved studies, respectively. Thus, scholars contributing to publications in a relatively technical field are exhibiting an apparent keenness toward exploring the managerial impact of the new technological phenomenon. 
Fig. 5. Publication trend over time

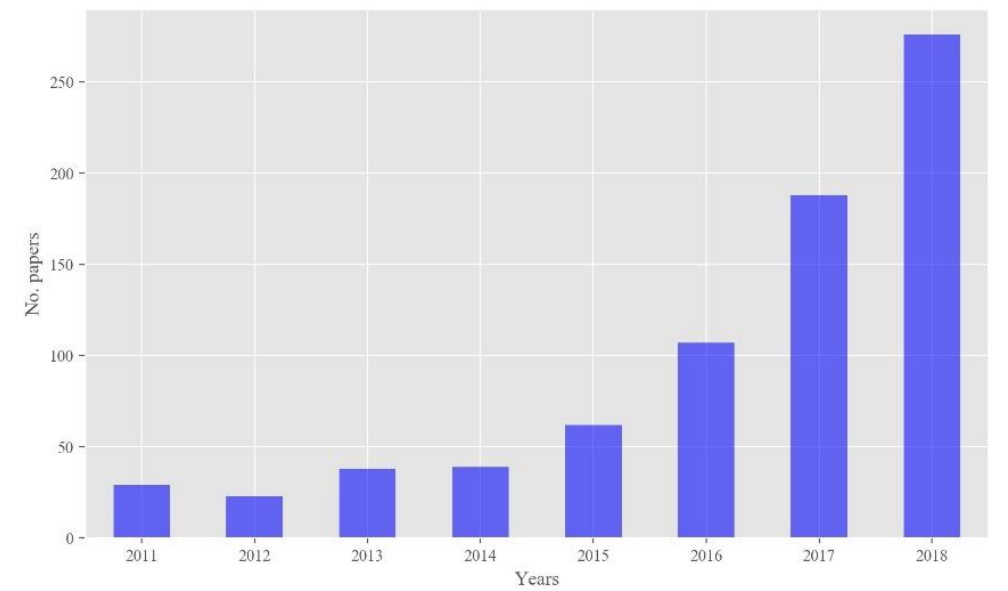

By taking the number of citations as a proxy of the relevance and importance of a study within the academic community, we observe that the most cited document in our sample is the work of Berman (2012), with 512 citations. In this study, the author conducts an in-depth examination of the characteristics of 3-D Printing, a technology depicted as the new industrial revolution. Other contributions with more than 100 citations include the work of Lee and Lee (2015), Zhong et al. (2015), Kang et al. (2016), and Ford and Despeisse (2016). As far as the authors are concerned, during the analyzed time window (January 2011 - October 2018), the most active authors had a maximum of four publications-Kai-Ingo Voigt from the Friedrich-Alexander-University Erlangen-Nürnberg (Germany), Morteza Ghobakhloo from the University of Hormozgan (Iran), and Fei Tao from the Beihang University (China).

We also analyzed and presented the ranking of the top 10 countries in terms of the number of affiliations (see Figure 7), and, interestingly, the "United States of America" and "Germany" led the ranking. This is consistent with the fact that these two countries have been the first to announce governmental plans aimed at boosting the introduction of industry 4.0 technologies in manufacturing companies, thereby leading the digital revolution in manufacturing. Interestingly, the other most represented countries are those that have closely followed Germany and the United States of America in supporting digital transformation through ad hoc governmental policies and plans. While the overall trend is not surprising if we interpret it in relation to the historical development of governmental plans, it differs markedly from the trend found by Liao et al. (2017), who showed Germany in the most dominant position vis-à-vis the other countries in the top 10 ranking. The discrepancy with the previous study can be attributed to a few factors. First, Liao et al. (2017) described industry 4.0 research without constraining it to specific subject areas. Second, and related to the previous point, German authors dealing with the industry 4.0 phenomenon have extensively written in the engineering and technological domains, therefore making the "dominance" of authors with German affiliation even more relevant. Finally, as the research on the managerial literature is 
vast and heterogeneous, management scholars dealing with industry 4.0 are affiliated with institutions more evenly distributed internationally.

Fig. 6. Top ten journals by number of publications

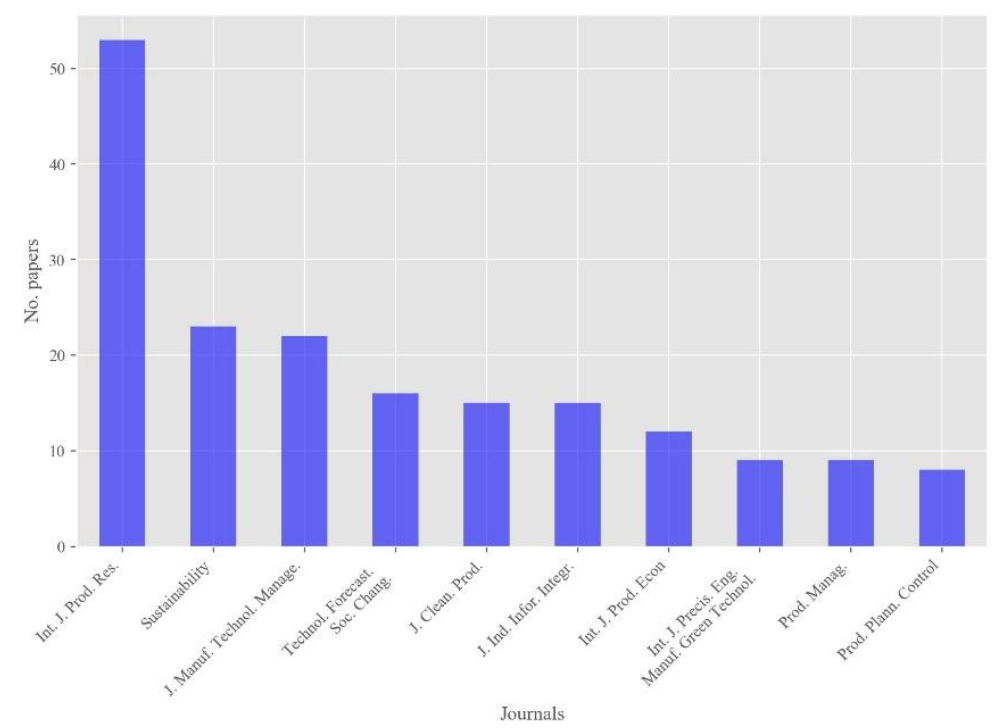

A detailed examination of the reference list shows that the most cited work, with 43 citations, is the report developed by the industrie 4.0 Working Group (Kagermann et al., 2013), which triggered the innovation wave related to the phenomenon. With 33 citations, this was followed by the article of Lee et al. (2015) that proposed a CPSs architecture for manufacturing systems in the industry 4.0 era. Finally, with 31 citations, the third place was taken by the conference paper of Hermann et al. (2016) that introduced industry 4.0 design principles (the rank, with further details, of the 20 most referred papers is available in the appendix).

Fig. 7. Top ten countries by number of affiliations

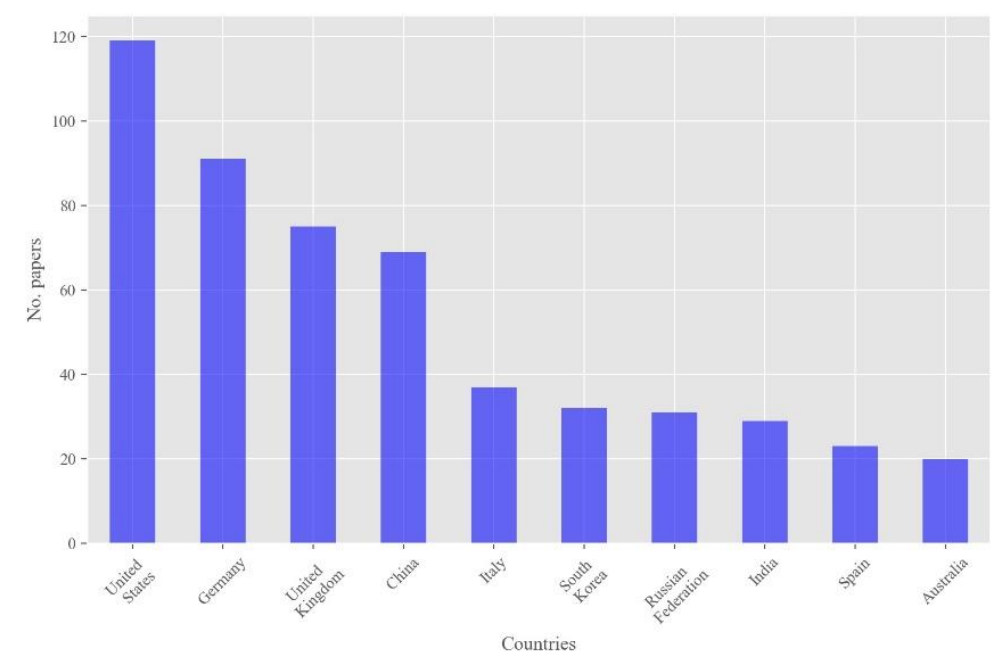




\subsection{Results of bibliographic coupling}

One of the aims of this manuscript is to provide a clear and comprehensible picture of the intellectual structure emerging from industry 4.0 in the managerial literature. To ensure objective and reproducible results, we adopted a systematic literature review methodology (Tranfield et al., 2003), namely bibliographical coupling that is particularly suitable when mapping emerging research fronts (Zupic and Čater, 2015).

In order to obtain a complete, yet parsimonious, set of results, we applied bibliographical coupling using different coupling thresholds on our initial set of collected documents (Mura et al., 2018). Figures 8, 9, 10, and 11 depict the selection and refinement processes, representing the bibliographical network and the communities found using different coupling thresholds. All the graphical representations have been made by using the software Gephi (Bastian et al., 2009) and applying the force atlas algorithm. Specifically, Figure 8 shows the bibliographical network developed by embedding all the retrieved documents, and Figure 9 depicts the findings derived by using a coupling threshold of 4 to infer similarity (i.e., embedding all the edges stemming from documents with at least a connection of weight equal to 4). Figures 10 and 11 represent the set of documents obtained using a coupling threshold of 8 , including all the ties and only the strong ties, respectively. During the synthesis, the overall structure of the network is preserved using different coupling thresholds. Eventually, we chose a coupling threshold of 8 to represent the main components of each community. Thus, to infer similarity between 2 documents, 8 shared references were needed. The resulting network, whose creation process has been detailed in Section 3, initially comprised 126 edges and 99 nodes belonging to 20 different communities. However, having assessed the content of each community, we decided to remove those containing only two nodes. These partitions of the network, in many cases, contained two manuscripts written by the same authors, contributing to noise inside the network itself (Zupic and Čater, 2015). Hence, we obtained the final network structure (visible in Figure 11), comprising 73 nodes and 113 edges; the network was divided into 7 communities by the Louvain algorithm, with a density of 0.043 , an average degree of 3.1 , and a clustering coefficient of 0.331 . Figure 11 illustrates the network structure derived after the analysis, wherein the nodes identify studies and an edge connects similar studies based on their shared references. The size of each node varies proportionally based on its degree (number of links), while the color reveals the belonging cluster. The node corresponds to the paper ID (linked to the study during the analysis phase); information regarding the document associated with this ID is outlined in the findings section, allowing the reader to gain a thorough understanding of the network structure.

As clearly depicted in Figure 11, the three distinctive main areas in the network are as follows: the first one includes communities 1 and 2; the second one encompasses communities 3, 4, and 5; and 
the last one consists of communities 6 and 7. Despite the fact that the three main components seem actually totally disconnected, there are certain weak linkages among them (connection with a weight less than the chosen threshold of 8, see Figure 10). Moreover, certain documents belong to a specific cluster but they share some edges with nodes in other communities. This is due to the fact that some retrieved studies appear to address themes of the two communities. For example, in the case of Müller et al. (2018a), at the border of community 1 and 2, the first part of the study includes a brief literature review on the term industry 4.0; this review aims to find an appropriate definition for their study, which is a topic close to the community 1 . However, the study mainly aims to assess the potential impact of industry 4.0 technologies on business model innovation - this is a theme that places the study closer to the topic of the community 2.

Given this network structure, the next sections conduct an in-depth examination of each of the seven communities extracted by the Louvain algorithm in order to understand the internal composition of these communities and to assess the topics explored within them. 


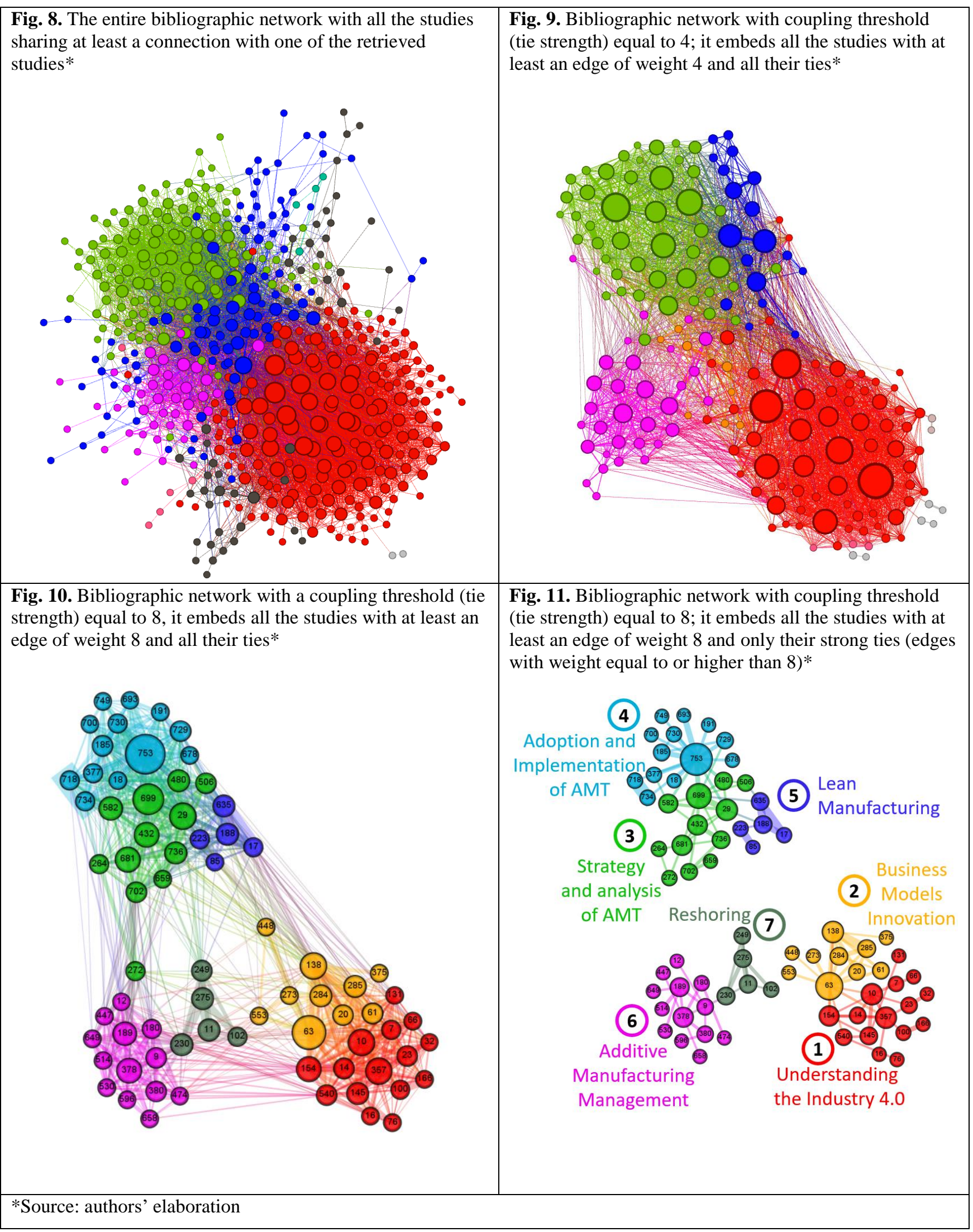




\subsubsection{Community 1: Understanding the Industry 4.0 phenomenon}

Table 2. Community 1 documents

\begin{tabular}{|c|c|c|c|c|}
\hline Index & Authors & Title & Year & Source title \\
\hline 7 & $\begin{array}{l}\text { Lopes de Sousa Jabbour } \\
\text { A.B., Jabbour C.J.C., } \\
\text { Godinho Filho M., and } \\
\text { Roubaud D. }\end{array}$ & $\begin{array}{l}\text { Industry } 4.0 \text { and the circular economy: A proposed research } \\
\text { agenda and original roadmap for sustainable operations }\end{array}$ & 2018 & $\begin{array}{l}\text { Annals of } \\
\text { Operations } \\
\text { Research }\end{array}$ \\
\hline 10 & Ghobakhloo M. & $\begin{array}{l}\text { The future of manufacturing industry: A strategic roadmap } \\
\text { toward Industry } 4.0\end{array}$ & 2018 & $\begin{array}{l}\text { Journal of } \\
\text { Manufacturing } \\
\text { Technology } \\
\text { Management }\end{array}$ \\
\hline 14 & $\begin{array}{l}\text { Dalenogare L.S., Benitez } \\
\text { G.B., Ayala N.F., and Frank } \\
\text { A.G. }\end{array}$ & $\begin{array}{l}\text { The expected contribution of industry } 4.0 \text { technologies for } \\
\text { industrial performance }\end{array}$ & 2018 & $\begin{array}{l}\text { International } \\
\text { Journal of } \\
\text { Production } \\
\text { Economics }\end{array}$ \\
\hline 16 & Li L. & $\begin{array}{l}\text { China's manufacturing locus in 2025: With a comparison } \\
\text { of "Made-in-China 2025" and "industry 4.0" }\end{array}$ & 2018 & $\begin{array}{l}\text { Technological } \\
\text { Forecasting and } \\
\text { Social Change }\end{array}$ \\
\hline 23 & Tsai W.-H. and Lu Y.-H. & $\begin{array}{l}\text { A framework of production planning and control with } \\
\text { carbon tax under industry } 4.0\end{array}$ & 2018 & $\begin{array}{l}\text { Sustainability } \\
\text { (Switzerland) }\end{array}$ \\
\hline 32 & Tsai W.-H. and Lai S.-Y. & $\begin{array}{l}\text { Green production planning and control model with } \mathrm{ABC} \\
\text { under industry } 4.0 \text { for the paper industry }\end{array}$ & 2018 & $\begin{array}{l}\text { Sustainability } \\
\text { (Switzerland) }\end{array}$ \\
\hline 66 & $\begin{array}{l}\text { de Sousa Jabbour A.B.L., } \\
\text { Jabbour C.J.C., Foropon C., } \\
\text { and Filho M.G. }\end{array}$ & $\begin{array}{l}\text { When titans meet - Can industry } 4.0 \text { revolutionise the } \\
\text { environmentally-sustainable manufacturing wave? The role } \\
\text { of critical success factors }\end{array}$ & 2018 & $\begin{array}{l}\text { Technological } \\
\text { Forecasting and } \\
\text { Social Change }\end{array}$ \\
\hline 76 & $\begin{array}{l}\text { Cheng J., Chen W., Tao F., } \\
\text { and Lin C.-L. }\end{array}$ & $\begin{array}{l}\text { Industrial IoT in } 5 \mathrm{G} \text { environment towards smart } \\
\text { manufacturing }\end{array}$ & 2018 & $\begin{array}{l}\text { Journal of } \\
\text { Industrial } \\
\text { Information } \\
\text { Integration }\end{array}$ \\
\hline 100 & Cozmiuc D. and Petrisor I. & Industrie 4.0 by Siemens: Steps made today & 2018 & $\begin{array}{l}\text { Journal of Cases } \\
\text { on Information } \\
\text { Technology }\end{array}$ \\
\hline 131 & $\begin{array}{l}\text { Moeuf A., Pellerin R., } \\
\text { Lamouri S., Tamayo-Giraldo } \\
\text { S., and Barbaray R. }\end{array}$ & $\begin{array}{l}\text { The industrial management of SMEs in the era of industry } \\
4.0\end{array}$ & 2018 & $\begin{array}{l}\text { International } \\
\text { Journal of } \\
\text { Production } \\
\text { Research }\end{array}$ \\
\hline 145 & $\begin{array}{l}\text { Wang X., Ong S.K., and Nee } \\
\text { A.Y.C. }\end{array}$ & $\begin{array}{l}\text { A comprehensive survey of ubiquitous manufacturing } \\
\text { research }\end{array}$ & 2018 & $\begin{array}{l}\text { International } \\
\text { Journal of } \\
\text { Production } \\
\text { Research }\end{array}$ \\
\hline 154 & Bibby L. and Dehe B. & $\begin{array}{l}\text { Defining and assessing industry } 4.0 \text { maturity levels-case of } \\
\text { the defence sector }\end{array}$ & 2018 & $\begin{array}{l}\text { Production } \\
\text { Planning and } \\
\text { Control } \\
\end{array}$ \\
\hline 166 & Cozmiuc D. and Petrisor I. & Industrie 4.0 by Siemens: Steps made next & 2018 & $\begin{array}{l}\text { Journal of Cases } \\
\text { on Information } \\
\text { Technology }\end{array}$ \\
\hline 357 & $\mathrm{Lu} \mathrm{Y.}$ & $\begin{array}{l}\text { Industry 4.0: A survey on technologies, applications and } \\
\text { open research issues }\end{array}$ & 2017 & $\begin{array}{l}\text { Journal of } \\
\text { Industrial } \\
\text { Information } \\
\text { Integration }\end{array}$ \\
\hline 540 & $\begin{array}{l}\text { Kang H.S., Lee J.Y., Choi S., } \\
\text { Kim H., Park J.H., Son J.Y., } \\
\text { Kim B.H., and Noh S.D. }\end{array}$ & $\begin{array}{l}\text { Smart manufacturing: Past research, present findings, and } \\
\text { future directions }\end{array}$ & 2016 & $\begin{array}{l}\text { International } \\
\text { Journal of } \\
\text { Precision } \\
\text { Engineering and } \\
\text { Manufacturing - } \\
\text { Green } \\
\text { Technology }\end{array}$ \\
\hline
\end{tabular}

This community is the core community related to the topic of industry 4.0 , and we labelled it as "Understanding the industry 4.0 phenomenon." Scholars are still looking to gain a deep understanding of the concept of industry 4.0 and its application in different fields. Starting at a higher 
granularity level, $\mathrm{Lu}$ (2017) provides a survey of the industry 4.0. Additionally, Cozmiuc and Petrisor (2018a, 2018b) analyze of Siemens's understanding of industrie 4.0 as a model for digital disruption, and identify the state of the art and future research directions on the subject. Moreover, Dalenogare et al. (2018) try to ascertain which of industry 4.0 technologies are expected to provide more benefits to the company, and Ghobakhloo (2018) provides a strategic roadmap that can prepare the industry for the advent of industry 4.0. As clarified by Moeuf et al. (2018), small and medium enterprises (SMEs) have not invested significantly on the digital technologies underpinning the fourth industrial revolution, with the exception of low cost technologies such as cloud computing and the IoTs. Comparing industry 4.0 with the initiative "Made in China 2025," Li (2018) investigated the relationship between socioeconomic changes and technological entrepreneurship in China, which is one of the most competitive emerging economies. The Chinese visionary strategical plan, which shares many similarities with the industry 4.0, is even more challenging and can be used by other emerging and advanced economies aiming at enhancing technological entrepreneurship activities.

Linking industry 4.0 with the phenomenon of the circular economy, Jabbour et al. (2018b) show how different industry 4.0 technologies can underpin circular economy strategies. Subsequently, Jabbour et al. (2018a) assess the possible synergies between industry 4.0 and environmentally sustainable manufacturing. On a more granular level, on the one hand, Kang et al. (2016) provide a literature review on the concept of smart manufacturing; they highlight the main structure of the phenomenon, its core technologies, and avenues for future research. As clearly stated by the authors, the term smart manufacturing is used as a synonym for the fourth industrial revolution in manufacturing. On the other hand, Wang et al. (2018) contributed to the ubiquitous manufacturing research by producing a comprehensive survey on the topic that is recognized as a realizable target set for the industry 4.0 vision. Leveraging on industry 4.0 tools and principles for a specific industry, Tsai and Lu (2018) develop a green production planning and control model for the paper industry; Tsai and Lai (2018) also propose the same model for the tyre industry, whose features are different from the paper industry. At a company level, Bibby and Dehe (2018) develop a model to assess the maturity level of the industry 4.0 phenomenon inside firms using three specific dimensions, namely people and culture, strategy, and factory of the future.

This cluster of studies highlights that scholars and practitioners lack a thorough and clear understanding of the industry 4.0 phenomenon. Nonetheless, the latter set of studies strive to gain a comprehensive understanding of the phenomenon (Ghobakhloo, 2018; Lu, 2017; Moeuf et al., 2018), focusing on different manufacturing industries (Tsai and Lai, 2018; Tsai and Lu, 2018) and identifying potential synergies with other economic phenomena (Jabbour et al., 2018a, 2018b). 


\subsubsection{Community 2: Business model innovation}

Table 3. Community 2 documents

\begin{tabular}{|c|c|c|c|c|}
\hline Index & Authors & Title & Year & Source title \\
\hline 20 & $\begin{array}{l}\text { Nagy J., Oláh J., Erdei E., } \\
\text { Máté D., and Popp J. }\end{array}$ & $\begin{array}{l}\text { The role and impact of industry } 4.0 \text { and the internet of } \\
\text { things on the business strategy of the value chain-the case } \\
\text { of Hungary }\end{array}$ & 2018 & $\begin{array}{l}\text { Sustainability } \\
\text { (Switzerland) }\end{array}$ \\
\hline 61 & Schneider P. & $\begin{array}{l}\text { Managerial challenges of industry } 4.0 \text { : an empirically } \\
\text { backed research agenda for a nascent field }\end{array}$ & 2018 & $\begin{array}{l}\text { Review of } \\
\text { Managerial Science }\end{array}$ \\
\hline 63 & $\begin{array}{l}\text { Müller J.M., Buliga O., and } \\
\text { Voigt K.-I. }\end{array}$ & $\begin{array}{l}\text { Fortune favors the prepared: How SMEs approach business } \\
\text { model innovations in industry } 4.0\end{array}$ & 2018 & $\begin{array}{l}\text { Technological } \\
\text { Forecasting and } \\
\text { Social Change }\end{array}$ \\
\hline 138 & $\begin{array}{l}\text { Müller J.M., Kiel D., and } \\
\text { Voigt K.-I. }\end{array}$ & $\begin{array}{l}\text { What drives the implementation of industry } 4.0 \text { ? The role } \\
\text { of opportunities and challenges in the context of } \\
\text { sustainability }\end{array}$ & 2018 & $\begin{array}{l}\text { Sustainability } \\
\text { (Switzerland) }\end{array}$ \\
\hline 273 & $\begin{array}{l}\text { Brooks C., Gherhes C., } \\
\text { Vorley T., and Williams N. }\end{array}$ & $\begin{array}{l}\text { The nature of publicly funded innovation and implications } \\
\text { for regional growth: Reflections from the Sheffield City } \\
\text { Region }\end{array}$ & 2018 & $\begin{array}{l}\text { Competitiveness } \\
\text { Review }\end{array}$ \\
\hline 284 & $\begin{array}{l}\text { Kiel D., Arnold C., and Voigt } \\
\text { K.-I. }\end{array}$ & $\begin{array}{l}\text { The influence of the Industrial Internet of Things on } \\
\text { business models of established manufacturing companies - } \\
\text { A business level perspective }\end{array}$ & 2017 & Technovation \\
\hline 285 & $\begin{array}{l}\text { Kiel D., Müller J.M., Arnold } \\
\text { C., and Voigt K.-I. }\end{array}$ & $\begin{array}{l}\text { Sustainable industrial value creation: Benefits and } \\
\text { challenges of industry } 4.0\end{array}$ & 2017 & $\begin{array}{l}\text { International } \\
\text { Journal of } \\
\text { Innovation } \\
\text { Management }\end{array}$ \\
\hline 375 & $\begin{array}{l}\text { Beier G., Niehoff S., Ziems } \\
\text { T., and Xue B. }\end{array}$ & $\begin{array}{l}\text { Sustainability aspects of a digitalized industry - A } \\
\text { comparative study from China and Germany }\end{array}$ & 2017 & $\begin{array}{l}\text { International } \\
\text { Journal of Precision } \\
\text { Engineering and } \\
\text { Manufacturing - } \\
\text { Green Technology }\end{array}$ \\
\hline 448 & $\begin{array}{l}\text { Yang M., Evans S., } \\
\text { Vladimirova D., and Rana P. }\end{array}$ & $\begin{array}{l}\text { Value uncaptured perspective for sustainable business } \\
\text { model innovation }\end{array}$ & 2017 & $\begin{array}{l}\text { Journal of Cleaner } \\
\text { Production }\end{array}$ \\
\hline 553 & Rayna T., and Striukova L. & $\begin{array}{l}\text { From rapid prototyping to home fabrication: How 3D } \\
\text { printing is changing business model innovation }\end{array}$ & 2016 & $\begin{array}{l}\text { Technological } \\
\text { Forecasting and } \\
\text { Social Change }\end{array}$ \\
\hline
\end{tabular}

The studies in this community have been categorized under the theme "Business model innovation," in the context of industry 4.0. Technological pose challenges to businesses that do not have an adequate business model (Rayna and Striukova, 2016). The main topic addressed by the documents in this community is how industry 4.0 (Kiel et al., 2017a, 2017b; Müller et al., 2018a; Nagy et al., 2018) or one of its core technologies (Rayna and Striukova, 2016; Yang et al., 2017), impacts business model innovation (Chesbrough, 2007). Moreover, some studies emphasize the sustainability aspects of the implementation of the industry 4.0 ecosystem (Kiel et al., 2017b; Müller et al., 2018b; Yang et al., 2017) — this topic overlaps between community 1 and 2 and, apparently, links them together.

Despite the infancy of the scholarly debate, all the authors in this cluster agree that industry 4.0 technologies and design principles can fundamentally disrupt any element of traditional manufacturing business model. Particularly, Kiel et al. (2017a) discover that the value proposition, internal infrastructure management, and customer relationships are the three main dimensions of a business model that are affected by the implementation of industry 4.0 initiatives. With an awareness of the industrial value creation through industry 4.0, Müller et al. (2018b) identify strategic, operational, and environmental and social opportunities as positive drivers of the implementation of 
industry 4.0 solutions. Looking at the value creation from a sustainable angle, Kiel et al. (2017b) use the triple bottom line framework to identify the benefits and challenges related to the adoption of the industry 4.0 solution for each dimension of the framework. They included three more aspects to their initial framework, such as data and information, technical integration, and public context, owing to their criticality in qualifying the industrial Internet as an effective solution for sustainable value creation.

Going beyond the core components of the business model and by considering the uncaptured business value, Yang et al. (2017) propose an innovative perspective to pursue sustainable business model innovation. As far as the technology is concerned, 3-D printing is found to be the technology that can most disruptively impact business model innovation. In fact, Rayna and Striukova (2016), leveraging on the study of the HASBRO company, propose the utilization of this technology for rapid prototyping of an entire business model rather than a mere object. This technology can provide companies the capabilities to try and test business ideas promptly. Finally, in his managerial systematic literature review, Schneider (2018) identifies the aforementioned business model as one of the prominent clusters that pose managerial challenges in the industry 4.0 landscape.

\subsubsection{Community 3: Strategy and analysis of AMT}

Table 4. Community 3 documents

\begin{tabular}{|c|c|c|c|c|}
\hline Index & Authors & Title & Year & Source title \\
\hline 29 & $\begin{array}{l}\text { Cheng Y., } \\
\text { Matthiesen R., } \\
\text { Farooq S., Johansen } \\
\text { J., Hu H., and Ma } \\
\text { L. }\end{array}$ & $\begin{array}{l}\text { The evolution of investment patterns on advanced } \\
\text { manufacturing technology (AMT) in manufacturing } \\
\text { operations: A longitudinal analysis }\end{array}$ & 2018 & $\begin{array}{l}\text { International Journal of } \\
\text { Production Economics }\end{array}$ \\
\hline 264 & $\begin{array}{l}\text { Mishra R., Pundir } \\
\text { A.K., and } \\
\text { Ganapathy L. }\end{array}$ & $\begin{array}{l}\text { Empirical assessment of factors influencing potential of } \\
\text { manufacturing flexibility in organization }\end{array}$ & 2018 & $\begin{array}{l}\text { Business Process } \\
\text { Management Journal }\end{array}$ \\
\hline 272 & $\begin{array}{l}\text { Eyers D.R., Potter } \\
\text { A.T., Gosling J., } \\
\text { and Naim M.M. }\end{array}$ & The flexibility of industrial additive manufacturing systems & 2018 & $\begin{array}{l}\text { International Journal of } \\
\text { Operations and } \\
\text { Production } \\
\text { Management }\end{array}$ \\
\hline 432 & Narkhede B.E. & $\begin{array}{l}\text { Advance manufacturing strategy and firm performance: An } \\
\text { empirical study in a developing environment of small- and } \\
\text { medium-sized firms }\end{array}$ & 2017 & Benchmarking \\
\hline 480 & $\begin{array}{l}\text { Kong T., Feng T., } \\
\text { and Ye C. }\end{array}$ & $\begin{array}{l}\text { Advanced manufacturing technologies and green innovation: } \\
\text { The role of internal environmental collaboration }\end{array}$ & 2016 & $\begin{array}{l}\text { Sustainability } \\
\text { (Switzerland) }\end{array}$ \\
\hline 506 & $\begin{array}{l}\text { Moyano-Fuentes J., } \\
\text { Sacristán-Díaz M., } \\
\text { and Garrido-Vega } \\
\text { P. }\end{array}$ & $\begin{array}{l}\text { Improving supply chain responsiveness through Advanced } \\
\text { Manufacturing Technology: the mediating role of internal and } \\
\text { external integration }\end{array}$ & 2016 & $\begin{array}{l}\text { Production Planning } \\
\text { and Control }\end{array}$ \\
\hline 582 & $\begin{array}{l}\text { Bello Pintado A., } \\
\text { Kaufmann R., and } \\
\text { Diaz-de-Cerio J. }\end{array}$ & $\begin{array}{l}\text { Advanced manufacturing technologies, quality management } \\
\text { practices, and manufacturing performance in the southern } \\
\text { cone of Latin America }\end{array}$ & 2015 & Management Research \\
\hline 659 & $\begin{array}{l}\text { Thomé A.M.T., } \\
\text { Sousa R.S., and Do } \\
\text { Carmo L.F.R.R.S. }\end{array}$ & Complexity as contingency in sales and operations planning & 2014 & $\begin{array}{l}\text { Industrial Management } \\
\text { and Data Systems }\end{array}$ \\
\hline 681 & $\begin{array}{l}\text { Kim M., Suresh } \\
\text { N.C., and } \\
\text { Kocabasoglu- } \\
\text { Hillmer C. }\end{array}$ & $\begin{array}{l}\text { An impact of manufacturing flexibility and technological } \\
\text { dimensions of manufacturing strategy on improving supply } \\
\text { chain responsiveness: Business environment perspective }\end{array}$ & 2013 & $\begin{array}{l}\text { International Journal of } \\
\text { Production Research }\end{array}$ \\
\hline
\end{tabular}




\begin{tabular}{|l|l|l|l|l|}
\hline 699 & $\begin{array}{l}\text { Bülbül H., } \\
\text { Omürbek N., } \\
\text { Paksoy T., and } \\
\text { Bektaş T. }\end{array}$ & $\begin{array}{l}\text { An empirical investigation of advanced manufacturing } \\
\text { technology investment patterns: Evidence from a developing } \\
\text { country }\end{array}$ & $\begin{array}{l}\text { Journal of Engineering } \\
\text { and Technology } \\
\text { Management - JET-M }\end{array}$ \\
\hline 702 & $\begin{array}{l}\text { Helkiö P. and } \\
\text { Tenhiälä A. }\end{array}$ & $\begin{array}{l}\text { A contingency theoretical perspective to the product-process } \\
\text { matrix }\end{array}$ & 2013 & $\begin{array}{l}\text { International Journal of } \\
\text { Operations and } \\
\text { Production } \\
\text { Management }\end{array}$ \\
\hline 736 & $\begin{array}{l}\text { Liu N., Roth A.V., } \\
\text { and Rabinovich E. }\end{array}$ & $\begin{array}{l}\text { Antecedents and consequences of combinative competitive } \\
\text { capabilities in manufacturing }\end{array}$ & 2011 & $\begin{array}{l}\text { International Journal of } \\
\text { Operations and } \\
\text { Production } \\
\text { Management }\end{array}$ \\
\hline
\end{tabular}

This cluster conducts the "Strategy and analysis of advanced manufacturing technologies (AMT)." The scholars here try to analyze the various impacts of AMT on the firm. AMT is considered a very familiar concept in the strategic manufacturing literature (Boyer and Pagell, 2000), which emerged with the introduction of computer in business organizations. However, the relationship and concepts associated with AMT that are analyzed in this group of documents, as in the case of Cheng et al. (2018), will gain importance after the introduction of industry 4.0 technologies. If we scrutinize the community, Eyers et al. (2018) and Mishra et al. (2018) find a positive impact of AMT on flexibility dimensions. Additionally, Kim et al. (2013) investigate the impact of manufacturing flexibility and technological dimensions of manufacturing strategy in improving supply chain responsiveness. Using an empirical study, Narkhede (2017) examine the link between a business strategy that uses advanced manufacturing technologies and firm performance. In the same research line, Pintado et al. (2015) focus on quality management practices related to AMT. In relation to investment strategies, Bülbül et al. (2013) and Cheng et al. (2018) assess the dynamic nature of investment patterns in AMT. The strategy must ascertain the fit of the investment with the overall objectives of the company (Cheng et al., 2018). Besides, despite the existence of different investment patterns, they seem to be insignificantly correlated with firm performance or ownership (Bülbül et al., 2013). Finally, Liu et al. (2011), considering a cumulative model, discover a positive relationship between AMT and a business unit's combinative competitive capabilities.

\subsubsection{Community 4: Adoption and implementation of AMT}

Table 5. Community 4 documents

\begin{tabular}{|l|l|l|l|l|}
\hline \multicolumn{1}{|c|}{ Index } & \multicolumn{1}{|c|}{ Authors } & \multicolumn{1}{|c|}{ Title } & Year & \multicolumn{1}{c|}{ Source title } \\
\hline 18 & $\begin{array}{l}\text { Altuntas S., Cinar O., and } \\
\text { Kaynak S. }\end{array}$ & $\begin{array}{l}\text { Relationships among advanced manufacturing technology, } \\
\text { innovation, export, and firm performance: Empirical } \\
\text { evidence from Turkish manufacturing companies }\end{array}$ & 2018 & Kybernetes \\
\hline 185 & $\begin{array}{l}\text { Kumar R., Singh H., and } \\
\text { Chandel R. }\end{array}$ & $\begin{array}{l}\text { Exploring the key success factors of advanced } \\
\text { manufacturing technology implementation in Indian } \\
\text { manufacturing industry }\end{array}$ & 2018 & $\begin{array}{l}\text { Journal of } \\
\text { Manufacturing } \\
\text { Technology } \\
\text { Management }\end{array}$ \\
\hline 191 & $\begin{array}{l}\text { Bhandari D., Singh R.K., and } \\
\text { Garg S.K. }\end{array}$ & $\begin{array}{l}\text { Justification of advanced manufacturing technologies for } \\
\text { small and medium enterprises from auto component sector: } \\
\text { AHP approach }\end{array}$ & $\begin{array}{l}\text { International } \\
\text { Journal of } \\
\text { Productivity and } \\
\text { Quality } \\
\text { Management }\end{array}$ \\
\hline
\end{tabular}




\begin{tabular}{|c|c|c|c|c|}
\hline 377 & Borges L.A. and Tan K.H. & $\begin{array}{l}\text { Incorporating human factors into the AMT selection: A } \\
\text { framework and process }\end{array}$ & 2017 & $\begin{array}{l}\text { International } \\
\text { Journal of } \\
\text { Production } \\
\text { Research }\end{array}$ \\
\hline 678 & $\begin{array}{l}\text { Lewis M., Åhlström P., } \\
\text { Yalabik B., and Mårtensson } \\
\text { P. }\end{array}$ & $\begin{array}{l}\text { Implementing advanced service technology in the public } \\
\text { sector: An exploratory study of the relevance and } \\
\text { limitations of insights from private sector manufacturing } \\
\text { technology implementation }\end{array}$ & 2013 & $\begin{array}{l}\text { Production } \\
\text { Planning and } \\
\text { Control }\end{array}$ \\
\hline 693 & Singh H. and Kumar R. & $\begin{array}{l}\text { Hybrid methodology for measuring the utilization of } \\
\text { advanced manufacturing technologies using AHP and } \\
\text { TOPSIS }\end{array}$ & 2013 & Benchmarking \\
\hline 700 & Goyal S. and Grover S. & $\begin{array}{l}\text { A fuzzy multi attribute decision making approach for } \\
\text { evaluating effectiveness of advanced manufacturing } \\
\text { technology - in Indian context }\end{array}$ & 2013 & $\begin{array}{l}\text { International } \\
\text { Journal of } \\
\text { Productivity and } \\
\text { Quality } \\
\text { Management }\end{array}$ \\
\hline 718 & $\begin{array}{l}\text { Scannell T.V., Calantone } \\
\text { R.J., and Melnyk S.A. }\end{array}$ & $\begin{array}{l}\text { Shop floor manufacturing technology adoption decisions: } \\
\text { An application of the theory of planned behavior }\end{array}$ & 2012 & $\begin{array}{l}\text { Journal of } \\
\text { Manufacturing } \\
\text { Technology } \\
\text { Management }\end{array}$ \\
\hline 729 & $\begin{array}{l}\text { Darbanhosseiniamirkhiz M., } \\
\text { and Ismail W.K. }\end{array}$ & $\begin{array}{l}\text { Advanced manufacturing technology adoption in SMEs: } \\
\text { An integrative model }\end{array}$ & 2012 & $\begin{array}{l}\text { Journal of } \\
\text { Technology } \\
\text { Management and } \\
\text { Innovation } \\
\end{array}$ \\
\hline 730 & Saberi S. and Yusuff R.M. & $\begin{array}{l}\text { An exploratory study into advanced manufacturing } \\
\text { technology (AMT) usage in Malaysian small- and medium- } \\
\text { sized enterprises (SMEs) }\end{array}$ & 2012 & $\begin{array}{l}\text { International } \\
\text { Journal of } \\
\text { Innovation and } \\
\text { Technology } \\
\text { Management }\end{array}$ \\
\hline 734 & $\begin{array}{l}\text { Scannell T.V., Melnyk S.A., } \\
\text { and Calantone R.J. }\end{array}$ & $\begin{array}{l}\text { Shop floor manufacturing technology adoption: An } \\
\text { adaptation of the technology acceptance model }\end{array}$ & 2011 & $\begin{array}{l}\text { International } \\
\text { Journal of } \\
\text { Manufacturing } \\
\text { Technology and } \\
\text { Management }\end{array}$ \\
\hline 749 & $\begin{array}{l}\text { Taha Z., Banakar Z., and } \\
\text { Tahriri F. }\end{array}$ & $\begin{array}{l}\text { Analytical hierarchy process for the selection of advanced } \\
\text { manufacturing technology in an aircraft industry }\end{array}$ & 2011 & $\begin{array}{l}\text { International } \\
\text { Journal of } \\
\text { Applied Decision } \\
\text { Sciences }\end{array}$ \\
\hline 753 & Singh H., and Khamba J.S. & $\begin{array}{l}\text { Utilisation of new technologies: A state-of-art-review and } \\
\text { future prospective }\end{array}$ & 2011 & $\begin{array}{l}\text { International } \\
\text { Journal of } \\
\text { Services and } \\
\text { Operations } \\
\text { Management }\end{array}$ \\
\hline
\end{tabular}

In this community, the prominent theme is the "adoption and implementation of AMT" inside the company boundaries. First, Singh and Khamba (2011) provide an overview of the utilization of new technologies within the company. This is the hub of the cluster analyzed. Specifically, some studies provide a theoretical model for facilitating adoption (Borges and Tan, 2017; Darbanhosseiniamirkhiz and Wan Ismail, 2012; Scannell et al., 2011), while others suggest a methodology to measure the effective degree of utilization of AMT (Goyal and Grover, 2013). Considering only SMEs, on the one hand Saberi and Yusuff (2012) claim that technology does not play a critical role for its users; on the other hand, Bhandari et al. (2018) argue that only a judicious application of AMTs can improve SMEs' performance. In their singular case study, Lewis et al. (2013), use an AMT model to assess a project in the service sector. Including top management support, technological-organizational adaption, and training as main elements of their model, they found many similarities but also some differences. 


\subsubsection{Community 5: Lean manufacturing implementation}

Table 6. Community 5 documents

\begin{tabular}{|c|c|c|c|c|}
\hline Index & Authors & Title & Year & Source title \\
\hline 17 & $\begin{array}{l}\text { Ghobakhloo M., } \\
\text { Azar A., and Fathi } \\
\text { M. }\end{array}$ & $\begin{array}{l}\text { Lean-green manufacturing: The enabling role of information } \\
\text { technology resource }\end{array}$ & 2018 & Kybernetes \\
\hline 85 & $\begin{array}{l}\text { Ismail K., Isa C.R., } \\
\text { and Mia L. }\end{array}$ & $\begin{array}{l}\text { Market competition, lean manufacturing practices and the role } \\
\text { of Management Accounting Systems (MAS) information }\end{array}$ & 2018 & Journal Pengurusan \\
\hline 188 & $\begin{array}{l}\text { Ghobakhloo M. and } \\
\text { Azar A. }\end{array}$ & $\begin{array}{l}\text { Business excellence via advanced manufacturing technology } \\
\text { and lean-agile manufacturing }\end{array}$ & 2018 & $\begin{array}{l}\text { Journal of } \\
\text { Manufacturing } \\
\text { Technology } \\
\text { Management } \\
\end{array}$ \\
\hline 223 & $\begin{array}{l}\text { Ismail K., Isa C.R., } \\
\text { and Mia L. }\end{array}$ & $\begin{array}{l}\text { Evidence on the usefulness of management accounting } \\
\text { systems in integrated manufacturing environment }\end{array}$ & 2018 & $\begin{array}{l}\text { Pacific Accounting } \\
\text { Review }\end{array}$ \\
\hline 635 & $\begin{array}{l}\text { Ghobakhloo M. and } \\
\text { Hong T.S. }\end{array}$ & $\begin{array}{l}\text { IT investments and business performance improvement: The } \\
\text { mediating role of lean manufacturing implementation }\end{array}$ & 2014 & $\begin{array}{l}\text { International Journal of } \\
\text { Production Research }\end{array}$ \\
\hline
\end{tabular}

Each document in the above group focuses on a specific AMT, the "Lean manufacturing (LM)" paradigm. This is one of the possible strategies that can guide manufacturing companies in their endeavors to attain desired outcomes and sustain their competitiveness over time. Particularly, scholars in this cluster evaluate the link between information technologies/advanced manufacturing technologies and the effective implementation of LM. Using a questionnaire-based survey, Ghobakhloo and Hong (2014) found that LM and IT are mutually interdependent and an investment in IT can enhance the level of LM implementation thus leading to improved business performance. AMT competency plays a critical role in ensuring the successful implementation of this process (Ghobakhloo and Hong, 2014). However, later in time, IT competences in LM were found to a lowerorder organizational capability (Ghobakhloo et al., 2018). Since LM implementation promotes environmental practices, the business value provided by IT competences must be assessed in terms of LM effectiveness and environmental management capabilities (Ghobakhloo et al., 2018). In the same research line, Ghobakhloo and Azar (2018) argue that AMT has a significant impact on the development of not just LM but also agile manufacturing (AG), wherein LM can be seen as a precursor of AM. However, LM positively contributes toward operational performance, while AM significantly impacts marketing and financial performance. Looking more in detail at the performance, Ismail et al. (2018a) claim that the use of management accounting system (MAS) information positively impacts the use of integrated manufacturing practices, which, in turn, positively impacts the firm performance. Two years after the aforementioned study, Ismail et al. (2018b) claimed that MAS has a positive mediating role in market competition, lean manufacturing, and organizational performance.

\subsubsection{Community 6: Additive manufacturing management}

Table 7. Community 6 documents

\begin{tabular}{|l|l|l|l|l|}
\hline Index & Authors & Title & Year & Source title \\
\hline
\end{tabular}




\begin{tabular}{|c|c|c|c|c|}
\hline 9 & $\begin{array}{l}\text { Chekurov S., } \\
\text { Metsä-Kortelainen } \\
\text { S., Salmi M., and } \\
\text { Roda I., Jussila A. }\end{array}$ & $\begin{array}{l}\text { The perceived value of additively manufactured digital spare } \\
\text { parts in industry: An empirical investigation }\end{array}$ & 2018 & $\begin{array}{l}\text { International Journal of } \\
\text { Production Economics }\end{array}$ \\
\hline 12 & $\begin{array}{l}\text { Martinsuo M. and } \\
\text { Luomaranta T. }\end{array}$ & $\begin{array}{l}\text { Adopting additive manufacturing in SMEs: exploring the } \\
\text { challenges and solutions }\end{array}$ & 2018 & $\begin{array}{l}\text { Journal of } \\
\text { Manufacturing } \\
\text { Technology } \\
\text { Management }\end{array}$ \\
\hline 180 & $\begin{array}{l}\text { Murmura F. and } \\
\text { Bravi L. }\end{array}$ & $\begin{array}{l}\text { Additive manufacturing in the wood-furniture sector: } \\
\text { Sustainability of the technology, benefits and limitations of } \\
\text { adoption }\end{array}$ & 2018 & $\begin{array}{l}\text { Journal of } \\
\text { Manufacturing } \\
\text { Technology } \\
\text { Management }\end{array}$ \\
\hline 189 & $\begin{array}{l}\text { Holmström J., } \\
\text { Liotta G., and } \\
\text { Chaudhuri A. }\end{array}$ & $\begin{array}{l}\text { Sustainability outcomes through direct digital manufacturing- } \\
\text { based operational practices: A design theory approach }\end{array}$ & 2018 & $\begin{array}{l}\text { Journal of Cleaner } \\
\text { Production }\end{array}$ \\
\hline 378 & $\begin{array}{l}\text { Khorram Niaki M. } \\
\text { and Nonino F. }\end{array}$ & $\begin{array}{l}\text { Additive manufacturing management: a review and future } \\
\text { research agenda }\end{array}$ & 2017 & $\begin{array}{l}\text { International Journal of } \\
\text { Production Research } \\
\end{array}$ \\
\hline 380 & $\begin{array}{l}\text { Li Y., Jia G., Cheng } \\
\text { Y., and Hu Y. }\end{array}$ & $\begin{array}{l}\text { Additive manufacturing technology in spare parts supply } \\
\text { chain: a comparative study }\end{array}$ & 2017 & $\begin{array}{l}\text { International Journal of } \\
\text { Production Research }\end{array}$ \\
\hline 447 & $\begin{array}{l}\text { Deradjat D. and } \\
\text { Minshall T. }\end{array}$ & $\begin{array}{l}\text { Implementation of rapid manufacturing for mass } \\
\text { customisation }\end{array}$ & 2017 & $\begin{array}{l}\text { Journal of } \\
\text { Manufacturing } \\
\text { Technology } \\
\text { Management }\end{array}$ \\
\hline 474 & $\begin{array}{l}\text { Ford S. and } \\
\text { Despeisse M. }\end{array}$ & $\begin{array}{l}\text { Additive manufacturing and sustainability: an exploratory } \\
\text { study of the advantages and challenges }\end{array}$ & 2016 & $\begin{array}{l}\text { Journal of Cleaner } \\
\text { Production }\end{array}$ \\
\hline 514 & $\begin{array}{l}\text { Holmström J., } \\
\text { Holweg M., } \\
\text { Khajavi S.H., and } \\
\text { Partanen J. }\end{array}$ & $\begin{array}{l}\text { The direct digital manufacturing (r)evolution: definition of a } \\
\text { research agenda }\end{array}$ & 2016 & $\begin{array}{l}\text { Operations } \\
\text { Management Research }\end{array}$ \\
\hline 530 & $\begin{array}{l}\text { Sasson A. and } \\
\text { Johnson J.C. }\end{array}$ & $\begin{array}{l}\text { The 3D printing order: variability, supercenters and supply } \\
\text { chain reconfigurations }\end{array}$ & 2016 & $\begin{array}{l}\text { International Journal of } \\
\text { Physical Distribution } \\
\text { and Logistics } \\
\text { Management }\end{array}$ \\
\hline 596 & $\begin{array}{l}\text { Chen D., Heyer S., } \\
\text { Ibbotson S., } \\
\text { Salonitis K., } \\
\text { Steingrímsson J.G., } \\
\text { and Thiede S. }\end{array}$ & $\begin{array}{l}\text { Direct digital manufacturing: Definition, evolution, and } \\
\text { sustainability implications }\end{array}$ & 2015 & $\begin{array}{l}\text { Journal of Cleaner } \\
\text { Production }\end{array}$ \\
\hline 649 & $\begin{array}{l}\text { Holmström J. and } \\
\text { Partanen J. }\end{array}$ & $\begin{array}{l}\text { Digital manufacturing-driven transformations of service } \\
\text { supply chains for complex products }\end{array}$ & 2014 & $\begin{array}{l}\text { Supply Chain } \\
\text { Management }\end{array}$ \\
\hline 658 & $\begin{array}{l}\text { Yoon H.-S., Lee J.- } \\
\text { Y., Kim H.-S., Kim } \\
\text { M.-S., Kim E.-S., } \\
\text { Shin Y.-J., Chu W.- } \\
\text { S., and Ahn S.-H. }\end{array}$ & $\begin{array}{l}\text { A comparison of energy consumption in bulk forming, } \\
\text { subtractive, and additive processes: Review and case study }\end{array}$ & 2014 & $\begin{array}{l}\text { International Journal of } \\
\text { Precision Engineering } \\
\text { and Manufacturing - } \\
\text { Green Technology }\end{array}$ \\
\hline
\end{tabular}

This group is mainly related to "Additive Manufacturing management." In fact, the documents analyzed different aspects related to the adoption of direct digital manufacturing at a firm level. Additive manufacturing management is a part of a recent and unexplored research line (Khorram Niaki and Nonino 2017). In this cluster of works, some documents propose a research agenda that can explore the managerial implications of the phenomenon (Chen et al., 2015; Holmström et al., 2018; Khorram Niaki and Nonino, 2017), and other exploratory studies focus on digital manufacturing applications of the phenomenon at a firm level (Chekurov et al., 2018; Li et al., 2017; Martinsuo and Luomaranta, 2018; Murmura and Bravi, 2018). This managerial research stream tries to understand the potential impact of the introduction of additive manufacturing techniques in companies; they mainly focus on the sustainability generated through the adoption of this concept in terms of the sources of innovation and the configuration of value chains (Deradjat and Minshall, 
2017; Ford and Despeisse, 2016; Holmström et al., 2016; Murmura and Bravi, 2018; Sasson and Johnson, 2016). This community, to a certain extent, complements and expands extant research, which specifically discusses how additive manufacturing can challenge established business models and create new ones (Jia et al., 2015; Jiang et al., 2017; Potstada et al., 2016). This is based on the notion that 3-D printing will drive a new industrial revolution (Berman, 2012).

\subsubsection{Community 7: Reshoring}

Table 8. Community 7 documents

\begin{tabular}{|l|l|l|l|l|}
\hline Index & \multicolumn{1}{|c|}{ Authors } & \multicolumn{1}{|c|}{ Title } & Year & \multicolumn{1}{|c|}{ Source title } \\
\hline 11 & $\begin{array}{l}\text { Moore M.E., } \\
\text { Rothenberg L., and } \\
\text { Moser H. }\end{array}$ & $\begin{array}{l}\text { Contingency factors and reshoring drivers in the textile and } \\
\text { apparel industry }\end{array}$ & 2018 & $\begin{array}{l}\text { Journal of } \\
\text { Manufacturing } \\
\text { Technology } \\
\text { Management }\end{array}$ \\
\hline 102 & $\begin{array}{l}\text { Ancarani A. and Di } \\
\text { Mauro C. }\end{array}$ & $\begin{array}{l}\text { Reshoring and industry 4.0: How often do they go together? } \\
\text { Tate W. }\end{array}$ & 2018 & $\begin{array}{l}\text { IEEE Engineering } \\
\text { Management Review }\end{array}$ \\
\hline 230 & $\begin{array}{l}\text { Nujen B.B., Halse } \\
\text { L.L., Damm R., and } \\
\text { Gammelsæter H. }\end{array}$ & $\begin{array}{l}\text { Managing reversed (global) outsourcing - the role of } \\
\text { knowledge, technology and time }\end{array}$ & 2018 & $\begin{array}{l}\text { World Review of } \\
\text { Intermodal } \\
\text { Transportation } \\
\text { Research }\end{array}$ \\
\hline 275 & $\begin{array}{l}\text { Barbieri P., } \\
\text { Ciabuschi F., } \\
\text { Fratocchi L., and } \\
\text { Vignoli M. }\end{array}$ & What do we know about manufacturing reshoring? & $\begin{array}{l}\text { Journal of } \\
\text { Manufacturing } \\
\text { Technology } \\
\text { Management }\end{array}$ \\
\hline
\end{tabular}

This is a very recent cluster, whose articles were published in 2018. They are related to the phenomenon of "reshoring" (i.e., bringing production activities back to the home country from where they were offshored), which is linked to the use of AMT. Following a literature review methodology, Barbieri et al. (2018) aim at understanding the phenomenon of reshoring, classifying extant literature in order to find key factors that lead companies to re-shore their production activities. Considering the technological layer, Barbieri et al. (2018) conclude formulating a research question related to the impact of industry 4.0 technologies on reshoring. After empirically analyzing this question, Ancarani and Di Mauro (2018) find neither a strong positive relationship among technologies belonging to the industry 4.0 domain, nor identify cost reduction as the reason behind the willingness to reshore. Moradlou and Tate (2018) focus on the areas benefited through additive manufacturing to ascertain the role of this technology in facilitating the phenomenon of reshoring in UK companies. Conducting a case study in Scandinavia, Nujen et al. (2018) shed light on the critical role played by knowledge in the case of reshoring. The results indicate that the analyzed company finds it challenging to renew and revive capabilities in order to perform advanced manufacturing back home. Resources like skilled workers, policy, and regulations must be considered by the company in case of reshoring (Moore et al., 2018). 


\subsection{Framework discussion}

With the aim of bringing all the communities together and allowing the reader to gain a clear understanding of the big picture of the literature analyzed and clustered, we created a comprehensive framework to summarize our findings (see Figure 12). A bottom-up approach will be used to describe the obtained framework. First, after scrutinizing the three main components of the network structure (see Figure 11), we used a technological layer to classify them into three distinctive categories, namely AMT (community 3, 4, and 5), industry 4.0 technologies (community 1 and 2), and additive manufacturing (community 6 and 7). They represent diverse streams of literature with different degrees of similarity among them. On the basis of this framework, we treated the studies investigating the impact and development of AMT, which act as an enabler layer, as the ones that facilitate the adoption and exploration of the industry 4.0 concept (Cheng et al., 2018; Szalavetz, 2018). In the industry 4.0 cluster, we inserted a 3-D printing layer since this is the reference technology in the realm of the additive manufacturing (Jiang et al., 2017; Rayna and Striukova, 2016), one of the core technologies of the $4^{\text {th }}$ Industrial Revolution, which has gained particular attention from management scholars in the last few years (see Community 6).

As far as industry 4.0 is concerned, it has been approached from multiple angles, including the related vision (Kagermann et al., 2013), its core technologies (Chiarello et al., 2018; Kang et al., 2016; Lu, 2017), and its design principles (Hermann et al., 2016). In order to understand the maturity of industry 4.0 adoption at a firm level, we connected the industry 4.0 block with the two other blocks, namely "strategy" and "people and organization," as suggested by Bibby and Dehe (2018). Particularly, on the left-hand side, as one of the possible strategies guided by the adoption of industry 4.0, we introduce a reshoring component (see Community 7). Concerning the investment decisions, compared to large enterprises, we find that SMEs may not have heavily invested in the digital revolution, with the exception of low-cost digital technologies, such as IoTs and Cloud computing, as illustrated by Moeuf et al. (2018). In the center of the figure, a big arrow connects industry 4.0 (Community 1) with business model innovation (Community 2), surpassing the sustainability layer, given that the concept of sustainability (economic, social, and environmental) (Kiel et al., 2017b) is present in both the discovered communities. As per Kiel et al. (2017a), the three dimensions of the business model, which are mainly impacted by the implementation of 4.0 initiatives, are value proposition, internal infrastructure management, and customer relationship. Concerning the sustainability theme and business model innovation, Jabbour et al. (2018b) propose a link between the circular economy and industry 4.0, offering insights on how to exploit industry 4.0 technologies in order to pursue different types of business model innovations within a circular economy vision. 
On the right-hand side, a big arrow runs through the entire framework based on the concept of lean manufacturing (see Community 5); it has been linked to the introduction of AMTs in the firm and it is also associated with the adoption of industry 4.0 since the latter is also capable of implementing the lean paradigm (Sanders et al., 2016). The arrow cuts through the sustainability layer, thus figuratively portraying a shift from lean manufacturing to green-lean manufacturing.

Along with the framework, we graphically represent how companies increasingly add services to their value offerings (Müller et al., 2018a) through the servitization processes. By embracing servitization paradigms and strategies, firms are changing their orientation from a product-centric to a customer-centric approach of doing business (Neely, 2008; Vandermerwe and Rada, 1988) and are moving from passive adopters to providers of industry 4.0 solutions (Müller et al., 2018a).

The theme of services will be analyzed in-depth in the next section, which will also highlight them as a promising future component of the fourth industrial revolution either in the manufacturing sector or in other industrial sectors.

Fig. 12. Conceptual framework of industry 4.0's managerial and social science literature (source: authors' elaboration)

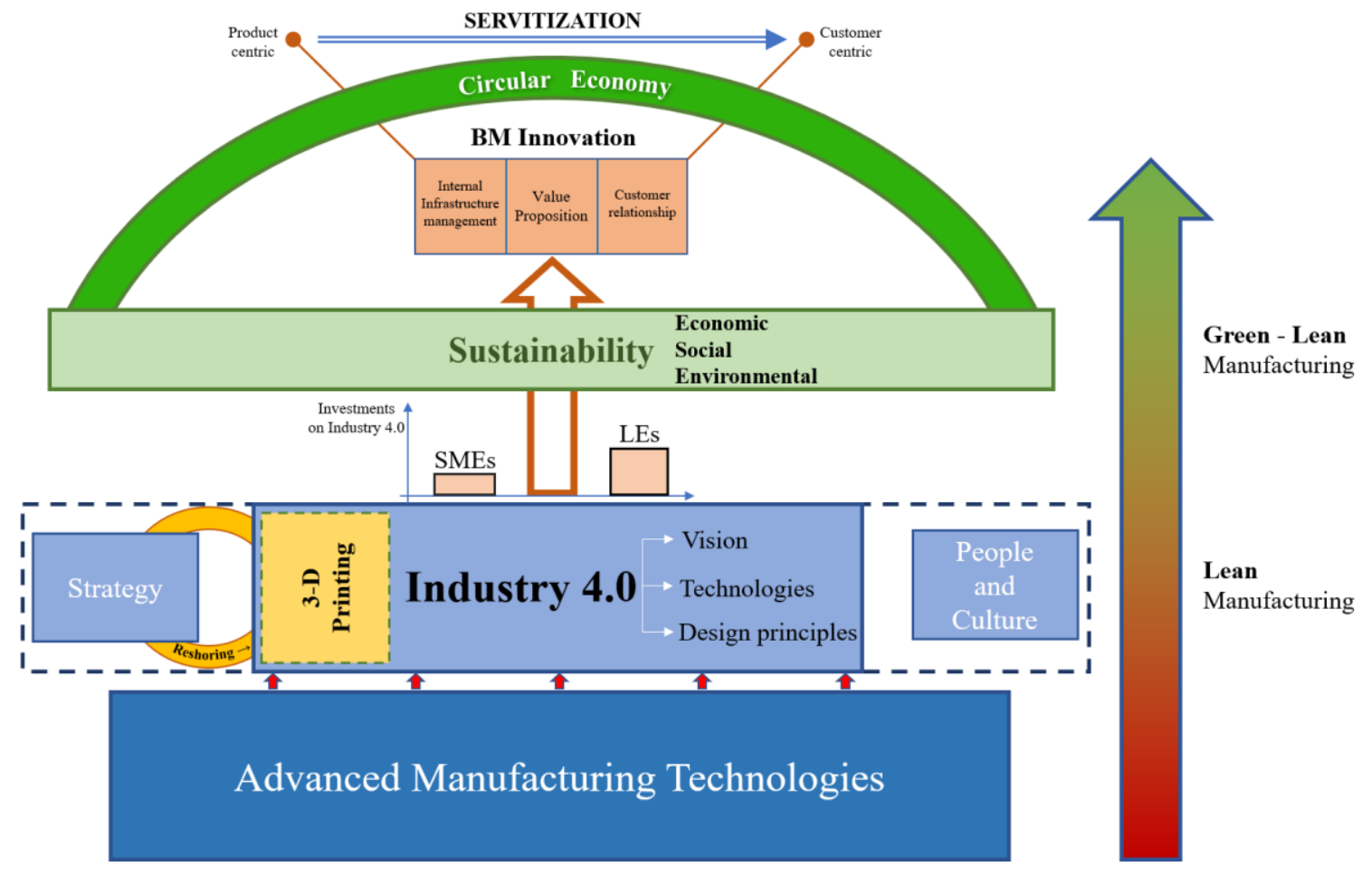

\subsection{Scientific production in relation to service industries}

With the aim of providing an answer to the second research question, we analyzed the full text of all the retrieved documents. In the first step of this analysis, we looked for keywords inside the text of the studies. At a more granular level, we conducted a preliminary analysis of the keyword "service," counting its absolute occurrences. As shown in Figure 13, the distribution of the term "service" among 
the set of collected studies is right skewed. Indeed, several documents presented the concept only a few times. Nevertheless, in the long tail of the distribution, wherein we placed a final bin for documents with over 60 occurrences, there seemed to be several documents that constantly employed the keyword "service."

Fig. 13. Distribution of the term "service" among the set of collected studies

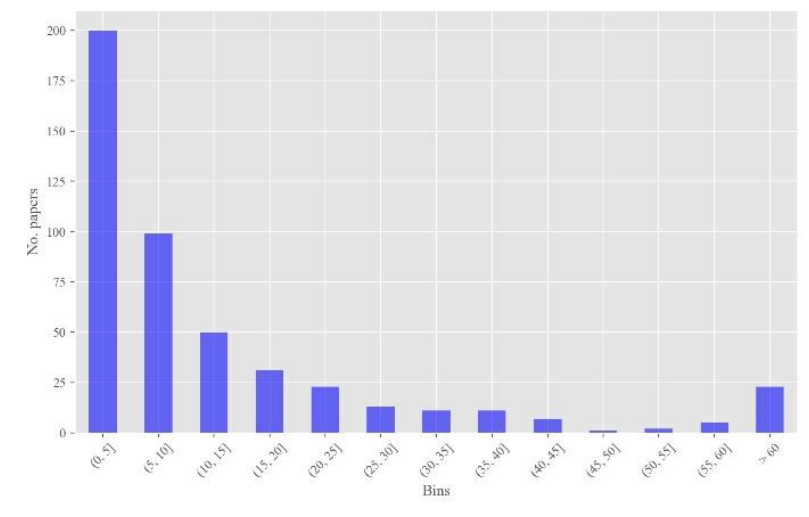

We conducted an in-depth examination to validate our preliminary insights. Specifically, we looked for the keywords "service* industr*" or "service* sector*," thus including all the possible combinations of the terms; the asterisk is a placeholder indicating the plural form. As depicted in Figure 14, despite the overall shape of the distribution remaining the same, the absolute frequencies witnessed a significant decline. In fact, 47 documents introduced the concepts once, and only 21 documents referred to the concepts more than once. With the results of this analysis in mind, we took a further step and analyzed the sentences related to the services referred to in the set of collected studies; we tried to capture their link with the industry 4.0 phenomenon.

Fig. 14. Distribution of "service* sector*" or "service* industr*" among the set of collected studies

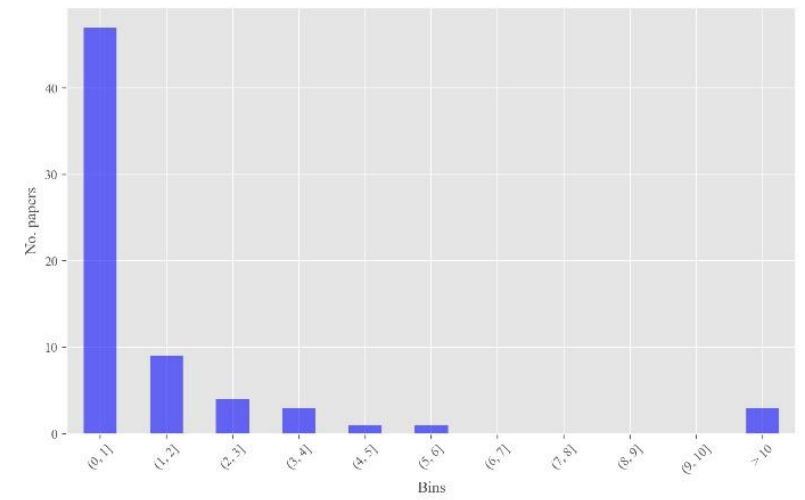

Among all the analyzed studies, Lee at al. (2014) first attempted to bridge the gap between industry 4.0 and servitization; they design a CPS framework for self-aware and self-maintenance machines, 
exploiting industry 4.0 technologies for service innovation and smart analytics. The authors state that the exploitation of the CPS framework in service innovation would lead companies to benefit from the information hidden in the industrial big data environment; they also argue that service innovation is one of the inevitable trends that drive the adoption of the industry 4.0 vision in manufacturing industries; they also pose challenges to the adoption of the phenomenon. However, the framework and case study proposed by the authors are rooted in engineering literature and are more useful to tackle technical aspects of the phenomenon under investigation rather than management ones.

From a business strategy perspective, the pioneering scholars dealing with services in Industry 4.0 were probably Kans and Ingwald (2016). They coined the term service management 4.0, which referred to the objective of a company to deliver value to its customers through its value proposition. Specifically, this new concept encompasses the following four key aspects: performance-based contracts, the business ecology concept, partnering, and the mix of product and services in the company's offers. The authors' conceptual framework clearly delineates the four levels of business development as logical steps that a company should undertake to transition from a product- to a solution (bundle of product and services) provider (fourth level). This last layer, from the authors' perspective, supports industry 4.0 from an industrial development point of view and refers to the service management 4.0. Nonetheless, despite the ability of the framework to help companies understand their current business models, the phases of the transformation process are not accurately linked to each other. Additionally, there is no empirical evidence to substantiate the conceptual framework.

A year after the aforementioned study, by adopting a multiple case study approach, Arnold et al. (2016) and Kiel et al. (2017a) provided qualitative empirical evidence to support the findings of Kans and Ingwald (2016). The former claimed that, for large companies undertaking industry 4.0 projects, service orientation would play a crucial role in enabling companies develop a more customer-centric view. This would imply an intensification of customer relationships and an extension of customer-oriented communication aimed at understanding customers' needs. Indeed, a large number of companies, in their samples, have been changing their value proposition to generate a bundle of products and services. In this data-driven servitization environment, the customer becomes a collaborative partner who must be integrated into the service and product design and engineering (Arnold et al., 2016). Since the Industrial IoT largely facilitates customization, Kiel et al. (2017a) argue that the natural consequence might be an individualized service orientation. Therefore, companies should always be ready to innovate their established business models in terms of hybrid and truly customizable product-service solutions by implementing industry 4.0 initiatives. In this regard, they should use, for example, pay-per-use and platform-based business models (Kiel et al., 
2017b). Nevertheless, in both their multiple case studies, using semi-structured interviews, Arnold et al. (2016) and Kiel et al. (2017a) analyzed large ${ }^{1}$ manufacturing firms. Despite operating in different industries, these firms were embedded in the German context. Thus, their findings lack generalizability for the manufacturing sector ${ }^{2}$. Additionally, as stated by Kiel et al. (2017a), their study should be extended to service providers to facilitate an investigation on potential discrepancies that emerge during the transition of these firms from product- to solution-based strategies; the study also sheds light on the intensities of the business model components' modifications. As indicated by Bienhaus and Haddud (2018), the examination of the phenomenon of the digital revolution and transformation reveals a remarkable gap between the manufacturing sector and the service sector.

Adopting the same methodological approach as Kiel et al. (2017a), Müller et al. (2018a) highlight that German $\mathrm{SMEs}^{3}$ active in the manufacturing industry must also pursue the objective of service business model innovation. The result of their study points out that "servitization allows new forms of value capture and that companies, which introduce services in their value offers, are the ones likely to profit the most from value capture innovation through industry 4.0" (Müller et al., 2018a). To a certain extent, these findings expand the literature review of Moeuf et al. (2018), who point out that when pursuing industry 4.0 initiatives, SMEs seem to limit their investments to the adoption of IoT and cloud computing. These technologies, despite not being elaborated by Müller et al. (2018a) (who consider CPS as the technological driver of industry 4.0 in their survey), may be the ones that allow companies to pursue servitization paths. It will be interesting in future studies to unpack the findings of Müller et al. (2018a) and explore how the wider set of technologies related to industry 4.0 can guide servitization in companies.

Concerning studies conducted outside the German borders, Bonfanti et al. (2018), exploring the digital manufacturing strategies developed by Italian craft firms, derive three different strategic implications. They are as follows: 1) taking advantage of the use of new digital technologies, 2) expanding the firm network of business partners and transforming customers into partners who can contribute toward design and production, and 3) surrounding products with a wider constellation of services. According to the authors, undertaking a strategy that embraces the three aforementioned strategies might allow companies to survive and potentially increase their competitive advantage. Thus, the three critical factors that contribute toward a successful industry 4.0 journey are technology, a customer-centric view, and servitization.

\footnotetext{
${ }^{1}$ More than $80 \%$ of the samples are made by firms with more than 1,000 employees.

${ }^{2}$ For example, SMEs account for $99 \%$ of the companies located in the EU.

${ }^{3}$ They consider SMEs as companies with a headcount below 500 employees and an annual turnover below 50 million euros.
} 
This service-orientation will be guided a considerable amount of data stemming from both the physical and digital worlds. Simply put, "The fourth industrial revolution is based on data" (Nagy et al., 2018). Talking about the strategy to address the industry 4.0 phenomenon, Müller et al. (2018b), clearly state that: "Data play a critical role in this context, since an increasing fusion of physical products and services with digital, data-centered enhancements and solutions is expected. A consequent orientation towards services is expected, which accelerates the vanishing separation between product manufacturing and service provision." Their results are in line with Yang et al. (2017), who analyze product-service systems' firms using AMTs and show that the dimension of the "uncaptured value" related to the mid-phase of the product lifecycle is mainly related to absence of service data. The availability of data, on the basis of the wisdom hierarchy (Rowley, 2007), will create opportunities to generate new business knowledge. By using AMTs, automation, and sensing and information technologies, organizations can collect and store service data in real-time, which, analyzed and manipulated through big data analytics techniques, can potentially create massive value for the company (Yang et al., 2017). It must be noted that data itself does not provide competitive advantage (Porter and Heppelmann, 2014). However, it can be the source of digital services that can create value for both customers and companies, and thereby enhance the complexity of the business model innovation process (Frank et al., 2019).

Overall, our findings seem to suggest that industry 4.0 research pertaining to service industries is still at a very embryonic stage. For instance, in his very recent literature review, Schneider (2018) put forward several research questions that need to be addressed, such as, "What digital services are actually demanded or most urgently needed? For which of these services are the customers willing to pay (and how much)?"[...]"Will Industry 4.0 technologies (thus) provide the possibility to overcome the service paradox (cf., Cenamor et al., 2017)?'Most of these interrelated questions remain unanswered in the service industries and, generally, the tertiary sector. Moreover, while some servitization scholars (Adrodegari and Saccani, 2017; Baines et al., 2017) adopted a service-dominant logic (Vargo and Lusch, 2004, 2008, 2016), so far no study has addressed how industry 4.0 technologies can help companies and customers co-create value, with the exception of the work of Rayna and Striukova (2016). They studied HASBRO to show how additive manufacturing (3-D printing) can be used for rapid prototyping of business models rather than objects; this process can be driven by collaboration with users who would construct their own models online. However, still this latter analysis pertains to the manufacturing industry.

Despite the increasing emphasis of policymakers to develop an agenda for industry 4.0 in the service industries (see the "smart service world" initiative launched by the German government in 2017), scholarly work is lagging behind, with only a few exceptions. For instance, within the growing 
research stream discussing servitization and the service business model innovation, the study of Rennung et al. (2016) is rather unique, as it points out that services have been largely neglected by industry 4.0 scholars. In their study, the authors conduct a survey on 80 well-established service provider companies by focusing on the effect of industry 4.0 on different phases of the service lifecycle. In their conclusions, the authors claim that "the service engineering and management can be an important component of the project "Industry 4.0." Their results have been corroborated by the recent exploratory research conducted by Nagy et al. (2018) on Hungarian companies, in which part of the study sample consisted of logistic service companies. Service companies embracing the industry 4.0 paradigm and vision were found capable of increasing market and financial performance and enhancing their competitiveness by improving the level of the services, cooperation capabilities, and business processes.

To sum up, managerial research on industry 4.0 has been mainly confined to the manufacturing sector. Indeed, services have been examined mainly by industry 4.0 scholars; they have addressed servitization within the manufacturing industries from both an engineering perspective (Lee et al., 2014) and a managerial one (Kans and Ingwald, 2016). As such, services have not been considered as an application field of industry 4.0 technologies. However, services have been viewed as a way of augmenting products by servitization mechanisms, turning manufacturing firms into industry 4.0 solution providers rather than mere product providers (Müller et al., 2018a). Indeed, servitization creates a "grey area" whereby manufacturing companies juxtapose products with services and adopt a customer-centric perspective (Kiel et al., 2017a), by which the provision of services to the customer enriches the provision of products. In this "grey area," products and services co-exist and increasingly contribute to blur the boundaries between the manufacturing and service industries (Lee et al., 2014). With the exception of a very few exploratory studies (Frank et al., 2019; Nagy et al., 2018), much remains to be done in terms of conceptual and, especially, empirical studies (for instance, using large-scale samples of firms within and across different service industries and countries). This will facilitate an understanding of the evolution of the industry 4.0 apparatus of technologies and solutions in the service industries and, more generally, the tertiary sector.

\section{Discussion and conclusions}

This study, as one of the outputs of a wider set of projects surrounding the phenomenon of industry 4.0, makes two relevant contributions. First, the study portrays the intellectual structure of the emerging managerial and social sciences literature related to industry 4.0 through a systematic quantitative literature review, which is matched with social network analysis. Second, it explores if and how management scholars embedded the service industries in the wide industry 4.0 paradigm 
and studied the service industries as an application field of industry 4.0. By embracing a quantitative systematic literature review approach, the manuscript investigates the industry 4.0 phenomenon, related plans and projects, and its potential evolution in the service industries domain.

The novelty of the proposed systematic quantitative literature review is first based on the idea that, to the best of our knowledge, this is the first attempt to examine the role of service industries through the lenses of the industry 4.0 literature. Second, part of the novelty is also related to the methodological perspective of the study. The study leverages on a data-driven approach, which is innovative; to the best of our knowledge, this approach is absent in existing reviews on the industry 4.0 phenomenon in the domain of social sciences and management studies (Piccarozzi et al., 2018; Schneider, 2018). Furthermore, we conduct a more granular analysis, leveraging on a wider set of keywords. We also provide a clear visualization of the thematic clusters of the literature by applying a community discovery algorithm to the results of the bibliometric technique. Third, with the aim of providing a better understanding of the research streams and topics studied by management and social sciences' scholars, we propose a framework that maps out the most substantial findings stemming from the network structure describing the extant literature. Despite the fact that the visualization does not claim to comprise all the efforts of the managerial scholars, it can be easily used by academics and practitioners to enhance their understanding and knowledge of the main emerging managerial aspects related to industry 4.0 ; it will also help them to discover original avenues for future research on this ongoing industrial revolution.

In terms of methodology, the authors adopted the bibliographical coupling method because this approach has the potential to identify emerging research fields and streams in relevant literature.

As far as the key findings are concerned, by adopting a data-driven approach to analyze relevant articles, we identified three main managerial and social science research areas-AMTs, additive manufacturing, and industry 4.0 technologies. With the aim of broadening the perspective on the emerging managerial and social sciences literature related to the industry 4.0 phenomenon, we linked the themes in an overarching framework (see Figure 12). We also detected the unique features of the articles and identified the recurrent theme for each community of articles through social network analysis.

We also found that the available managerial literature on the role of industry 4.0 in service industries is still scant, and it is mostly related to servitization mechanisms and processes in the manufacturing sector. Scholarly work on the role of industry 4.0 in service industries is at an embryonic stage, with most of the studies exhibiting an exploratory nature or merely claiming that more work is needed to gain a full understanding of the evolution of the industry 4.0 phenomenon in the tertiary sector. Accordingly, except for a very few exploratory studies (e.g., Nagy et al., 2018), a 
substantial amount of conceptual and empirical work must be carried out to comprehend the evolution of the industry 4.0 apparatus of technologies and solutions in the service industries. Consequently, we expect that, in the near future, management scholars dealing with the industry 4.0 phenomenon will orient their intellectual efforts and research agendas toward the service industries, as implicitly induced from recent literature (Müller et al., 2018a). Moreover, although service engineering and management seem to be important components embedded in industry 4.0 (Rennung et al., 2016), there is still a remarkable knowledge gap on the role of the industry 4.0 phenomenon and underpinning technologies in the service industries (Bienhaus and Haddud, 2018).

The following research agenda emerges from the systematic quantitative literature review. First, we encourage management and social sciences' scholars interested in industry 4.0 to i) rely on the overarching framework developed in this study (see Figure 12) to improve their research position and ii) strengthen the framework by systematizing future literature. Second, we strongly believe that future intellectual efforts should address, both conceptually and, especially, empirically, the role played by industry 4.0 technologies and design principles in the service sector. Third, we encourage scholars to improve our understanding of the antecedents and consequences of the industry 4.0 paradigm, technologies, and design principles within service industries by combining meaningful theoretical approaches and emerging disciplinary fields, such as the institutional theory, digital entrepreneurship, the service-dominant logic, and digital business models. The institutional theory would provide the relevant theoretical lens, especially at the backdrop of governmental plans designed to further develop digital technologies underpinning the industry 4.0 phenomenon in service industries (e.g., the "smart service world" initiative launched by the German government in 2017). Accordingly, it seems that, for service industries, like for the manufacturing ones, policymakers pose as key stakeholders that proactively shape the preliminary conditions for facilitating or catalyzing digital transformation. Therefore, an institutional theory perspective (DiMaggio and Powell, 1983; Meyer and Rowan, 1977; Zhao et al., 2017) might be able to better capture the role of governmental institutions in driving digital transformation in the tertiary sector. Second, so far, no study has conducted an in-depth examination of the role of digital entrepreneurs as well as distributed agency in digital platforms and ecosystems (e.g., Eisenmann et al., 2011; Evans, 2003; Evans and Schmalensee, 2016; Hagiu, 2014; Nambisan, 2017; Nambisan et al., 2019; Parker and Van Alstyne, 2018; Rochet and Tirole, 2006) in triggering and/or "enacting" industry 4.0 within the service industries. This certainly presents a relevant area of development for digital entrepreneurship scholars. Third, the specificity of the service industries might require scholars to embrace a servicedominant logic to better understand how the technologies underpinning Industry 4.0 might affect the service industries (Lusch et al., 2008; Lusch and Vargo, 2014; Vargo and Lusch, 2004, 2008). Fourth, 
certainly, an insightful application of business model innovation concepts is required for analyzing the role of digital technologies in shaping novel value propositions in the service industries. This will enhance the understanding of the processes of value creation, delivery, and capture (Amit and Zott, 2001, 2012; Spieth et al., 2014; Zott and Amit, 2007, 2010; Zott et al., 2011). Overall, given that the locus of agency, in reality, is shared across multiple stakeholders in the digitized service sector (including governments and digital entrepreneurs), future scholars might decide to use a combination of two or more of the aforementioned theoretical lenses, emerging disciplinary fields, and approaches (namely institutional theory, digital entrepreneurship theory, S-D logic, and business model innovation). By mindfully mixing the aforementioned approaches and lenses, management scholars might gain a comprehensive and holistic understanding of the interactions of different stakeholders for co-creating value within the digitized service industries.

This research is not without limitations. Despite being part of the novelty of the study, the methodological approach deployed in the analysis exhibits strengths and weaknesses. Indeed, although bibliometric analysis techniques are gaining scholarly consensus as effective methods to map out the structure of the literature in a given field of study, they can have a few drawbacks (Mura et al., 2018). By exclusively relying on citation analysis, bibliographical coupling can enhance visibility on articles with a long reference list (Vogel and Güttel, 2013), such as literature reviews. Furthermore, it does not capture the reason that leads some authors to refer to a particular citation (Zupic and Čater, 2015). Moreover, as a method of dimensionality reduction, the findings significantly depend on the thresholds chosen as cut-off values to obtain the citation network. Hence, we tried different thresholds when conducting a robustness check. Finally, future literature reviews, by applying bibliometric techniques, can investigate if and to what extent the access to a manuscript plays a role in influencing the results of the analysis.

Regardless of the aforementioned methodological limitations, we believe that the study offers a clear and robust contribution by enhancing our understanding of the intellectual structure of the emerging managerial and social sciences related to the industry 4.0 phenomenon. It also highlights the importance of a future orientation of scholarly attention to services and service industries. 


\section{References}

A. Ancarani, C. Di Mauro, Reshoring and industry 4.0: how often do they go together?, IEEE Eng. Manag. Rev. 46(2) (2018) 87 96. https://doi.org/10.1109/EMR.2018.2833475.

A. Bonfanti, M. Del Giudice, A. Papa, Italian craft firms between digital manufacturing, open innovation, and servitization, J. Knowl. Econ. 9(1) (2018) $136 \quad 149$. https://doi.org/10.1007/s13132-015-0325-9

A. Cipriani, J. Geddes, Comparison of systematic and narrative reviews: the example of the atypical $\begin{array}{lllllll}\text { antipsychotics, } & \text { Epidemiol. } & \text { Psych. } & \text { Sci. } & 12(3) & (2003) & 146\end{array}$ https://doi.org/10.1017/s1121189x00002918.

A. Gilchrist, Industry 4.0, 2016. doi:10.1007/978-1-4842-2047-4.

A. Hagiu, Strategic decisions for multisided platforms. MIT Sloan Manag. Rev. 55(2) (2014) 7180.

A. Moeuf, R. Pellerin, S. Lamouri, S. Tamayo-Giraldo, R. Barbaray, The industrial management of SMEs in the era of industry 4.0, Int. J. Prod. Res. 56(3) (2018) 11181136. https://doi.org/10.1080/00207543.2017.1372647.

A. Neely, Exploring the financial consequences of the servitization of manufacturing, Oper. Manag. Res. 1(2) (2008) 103 118. https://doi.org/10.1007/s12063-009-0015-5.

A. Sanders, C. Elangeswaran, J. Wulfsberg, Industry 4.0 implies lean manufacturing: research activities in industry 4.0 function as enablers for lean manufacturing, J. Ind. Eng. Manag. 9(3) (2016) 811 833. https://doi.org/10.3926/jiem.1940.

A. Sasson, J. C. Johnson, The 3D printing order: variability, supercenters and supply chain reconfigurations, Int. J. Phys. Distr. Log. Manag. 46(1) (2016) 8294. https://doi.org/10.1108/ijpdlm-10-2015-0257.

A. Syska, P. Liévre, Illusion 4.0: Deutschlands naiver traum von der smarten fabrik, CETPM Publishing, 2016.

A. Szalavetz, Industry 4.0 and capability development in manufacturing subsidiaries, Technol. Forecast. Soc. Change (2018) in press. https://doi.org/10.1016/j.techfore.2018.06.027.

A.B.L.D.S. Jabbour, C.J.C. Jabbour, C. Foropon, M.G. Filho, When titans meet - can industry 4.0 revolutionise the environmentally-sustainable manufacturing wave? The role of critical success $\begin{array}{llllllll}\text { factors, } & \text { Technol. } & \text { Forecast. } & \text { Soc. } & \text { Change } & 132 & \text { (2018a) } & 18\end{array}$ https://doi.org/10.1016/j.techfore.2018.01.017.

A.B.L.D.S. Jabbour, C.J.C. Jabbour, M.G. Filho, D. Roubaud, Industry 4.0 and the circular economy: a proposed research agenda and original roadmap for sustainable operations, Ann. Oper. Res. 270(1-2) (2018b) 273 286. https://doi.org/10.1007/s10479-018-2772-8.

A. B. Pintado, R. Kaufmann, J. Merino Diaz-de-Cerio, Advanced manufacturing technologies, quality management practices, and manufacturing performance in the southern cone of Latin America. Manag. Res. J. Iberoameric. Acad. Manag. 13(2) (2015) 187210. https://doi.org/10.1108/MRJIAM-03-2015-0580.

A.G. Frank, G.H. Mendes, N.F. Ayala, A. Ghezzi, Servitization and industry 4.0 convergence in the digital transformation of product firms: a business model innovation perspective, Technol. Forecast. Soc. Change 141 (2019) 341 351. https://doi.org/10.1016/j.techfore.2019.01.014. 
A.L. Barabási, Network science, Cambridge University Press, UK, 2016.

B. Berman, 3-D printing: the new industrial revolution, Bus. Horiz. 55(2) (2012) 155162.

B.B. Nujen, L.L. Halse, R. Damm, H. Gammelsæter, Managing reversed (global) outsourcing - the role of knowledge, technology and time, J. Manuf. Technol. Manag. 29(4) (2018) 676698. https://doi.org/10.1108/jmtm-02-2017-0023.

B.E. Narkhede, Advance manufacturing strategy and firm performance: an empirical study in a developing environment of small- and medium-sized firms, Benchmarking 24(1) (2017) 62101. https://doi.org/10.1108/bij-05-2015-0053.

C. Arnold, D. Kiel, K.-I.Voigt, How the industrial Internet of Things changes business models in different manufacturing industries. Int. J. Innov. Manag. 20(8) (2016) Article number 1640015. https://doi.org/10.1142/S1363919616400156.

C. Collberg, S. Kobourov, J. Nagra, J. Pitts, K. Wampler, A system for graph-based visualization of the evolution of software, In Proceedings of the 2003 ACM Symposium on Software Visualization (2003) 77-ff. https://doi.org/10.1145/774841.774844.

C. Hart, Doing a literature review: releasing the research imagination, Sage, 2018.

C. Pickering, J. Byrne, The benefits of publishing systematic quantitative literature reviews for PhD candidates and other early-career researchers, High. Educ. Res. Dev. 33(3) (2014) 534548. https://doi.org/10.1080/07294360.2013.841651.

C. Zott, R. Amit, Business model design and the performance of entrepreneurial firms, Org. Sci. 18 (2007) 181 199. https://doi.org/10.1287/orsc.1060.0232.

C. Zott, R. Amit, Designing your future business model: an activity system perspective, Long Range Plan. 43 (2010) 216 226. https://doi.org/10.1016/j.lrp.2009.07.004.

C. Zott, R. Amit, L. Massa, The business model: recent developments and future research, J. Manag. 37(4) (2011) 1019 1042. https://doi.org/10.1177/0149206311406265.

D. Bhandari, R.K. Singh, S.K. Garg, Justification of advanced manufacturing technologies for small and medium enterprises from auto component sector: AHP approach, Int. J. Prod. Qual. Manag. 23(4) (2018) 473 491. https://doi.org/10.1504/ijpqm.2018.10011181.

D. Chen, S. Heyer, S. Ibbotson, K. Salonitis, J.G. Steingrímsson, S. Thiede, Direct digital manufacturing: definition, evolution, and sustainability implications, J. Clean. Prod. 107 (2015) 615 625. https://doi.org/10.1016/j.jclepro.2015.05.009.

D. Cozmiuc, I. Petrisor, Industrie 4.0 by Siemens: steps made next, J. Case. Info. Technol. 20(1) (2018a) 31 45. https://doi.org/10.4018/jcit.2018010103.

D. Cozmiuc, I. Petrisor, Industrie 4.0 by Siemens: steps made today, J. Case. Info. Technol. 20(2) (2018b.) 30 48. https://doi.org/10.4018/jcit.2018040103.

D. Deradjat, T. Minshall, Implementation of rapid manufacturing for mass customization, J. Manuf. Technol. Manag. 28(1) (2017) 95 121. https://doi.org/10.1108/jmtm-01-2016-0007.

D. Giusto, A. Iera, G. Morabito, L. Atzori, The internet of things: 20th Tyrrhenian workshop on digital communications, Springer Science \& Business Media, 2010. https://doi.org/10.1007/9781-4419-1674-7.

D. Kiel, C. Arnold, K.I. Voigt, The influence of the industrial internet of things on business models of established manufacturing companies - a business level perspective, Technovation 68 (2017a) 
4 19. https://doi.org/10.1016/j.technovation.2017.09.003.

D. Kiel, J.M. Müller, C. Arnold, K.I. Voigt, Sustainable industrial value creation: benefits and challenges of industry 4.0, Int. J. Innov. Manag. 21(8) (2017b) Article number 1740015. https://doi.org/10.1142/s1363919617400151.

D. Lucke, C. Constantinescu, E. Westkämper, Smart factory-a step towards the next generation of manufacturing, In Manufacturing Systems and Technologies for the New Frontier, (2008) 11518. https://doi.org/10.1007/978-1-84800-267-8_23.

D. O'Halloran, E. Kvochko, Industrial internet of things: unleashing the potential of connected products and services, In World Economic Forum, 40, 2015.

D. Tranfield, D. Denyer, P. Smart, Towards a methodology for developing evidence-informed management knowledge by means of systematic review, Br. J. Manag. 14(3) (2003) 207222. https://doi.org/10.1111/1467-8551.00375.

D. Zhao, A. Strotmann, Analysis and visualization of citation networks. Synthesis lectures on information concepts, retrieval, and services. Morgan \& Claypool Publishers, 2015.

D.P.F. Möller, Digital manufacturing/industry 4.0 guide to computing fundamentals in cyberphysical systems, Computer Communications and Networks, Springer, Heidelberg, 2016.

D.R. Eyers, A.T. Potter, J. Gosling, M.M. Naim, The flexibility of industrial additive manufacturing systems, Int. J. Oper. Prod. Manag. 38(12) (2018) 2313 2343. https://doi.org/10.1108/ijopm-042016-0200.

D.S. Evans, R. Schmalensee, Matchmakers: the new economics of multisided platforms, Harvard Business Review Press, 2016.

D.S. Evans, Some empirical aspects of multi-sided platform industries, Rev. Netw. Econ. 2(3) (2003) 191209.

E. Garfield, From bibliographic coupling to co-citation analysis via algorithmic. A citationist's tribute to Belver C, Griffith, 2001.

E.A. Lee, Cyber physical systems: design challenges, In 11th IEEE Symposium on Object Oriented $\begin{array}{lllll}\text { Real-Time } & \text { Distributed } \quad \text { Computing } & \text { (ISORC), } & \text { (2008) } & 363\end{array}$ https://doi.org/10.1109/isorc.2008.25.

E.B. Reynolds, Y. Uygun, Strengthening advanced manufacturing innovation ecosystems: the case of Massachusetts, Technol. Forecast. Soc. Change $136 \quad$ (2018) $178 \quad 191$. https://doi.org/10.1016/j.techfore.2017.06.003.

E.S. Vieira, J.A.N.F. Gomes, A comparison of scopus and web of science for a typical university, Scientometrics 81(2) (2009) 587. https://doi.org/10.1007/s11192-009-2178-0.

E.Y. Zhao, G. Fisher, M. Lounsbury, D. Miller, Optimal distinctiveness: broadening the interface between institutional theory and strategic management, Strat. Manag. J. 38(1) (2017) 93113. https://doi.org/10.1002/smj.2589.

European Commission, Services 4.0, 2016a, retrieved from https://ec.europa.eu/commission/commissioners/20142019/bienkowska/announcements/services-40_en.

European Commission, The fourth industrial revolution, 2016b, retrieved from https://ec.europa.eu/\%0Adigital-single-market/en/fourth-industrial-revolution. 
F. Adrodegari, N. Saccani, Business models for the service transformation of industrial firms, Serv. Ind. J. 37(1) (2017) 57 83. https://doi.org/10.1080/02642069.2017.1289514.

F. Bienhaus, A. Haddud, Procurement 4.0: factors influencing the digitisation of procurement and supply chains, Bus. Process Manag. J. 24(4) (2018) 965 984. https://doi.org/10.1108/bpmj-062017-0139.

F. Chiarello, L. Trivelli, A. Bonaccorsi, G. Fantoni, Extracting and mapping industry 4.0 technologies $\begin{array}{lllllll}\text { using } \quad \text { Wikipedia, } & \text { Comput. } & \text { Ind. } & 100 & \text { (2018) } & 244\end{array}$ https://doi.org/10.1016/j.compind.2018.04.006.

F. Galati, B. Bigliardi, Industry 4.0: emerging themes and future research avenues using a text mining approach, Comp. Ind. 109 (2019) 100 113. https://doi.org/10.1016/j.compind.2019.04.018.

F. Jia, X. Wang, N. Mustafee, L. Hao, Investigating the feasibility of supply chaincentric business models in 3D chocolate printing: a simulation study, Technol. Forecast. Soc. Change 102 (2015) 202 213. https://doi.org/10.1016/j.techfore.2015.07.026.

F. Murmura, L. Bravi, Additive manufacturing in the wood-furniture sector: sustainability of the technology, benefits and limitations of adoption, J. Manuf. Technol. Manag. 29(2) (2018) 350 371. https://doi.org/10.1108/jmtm-08-2017-0175.

F. Rennung, C.T. Luminosu, A. Draghici, Service provision in the framework of industry 4.0, Proc. Soc. Behav. Sci. 221 (2016) 372 377. https://doi.org/10.1016/j.sbspro.2016.05.127.

F. Strozzi, C. Colicchia, A. Creazza, C. Noè, Literature review on the 'smart factory' concept using bibliometric tools, Int. J. Prod. Res. 55(22) (2017) $6572 \quad 6591$. https://doi.org/10.1080/00207543.2017.1326643.

G. Parker, M. Van Alstyne, Innovation, openness, and platform control, Manag. Sci. 64(7) (2018) 3015 3032. https://doi.org/10.1287/mnsc.2017.2757.

G. Reischauer, Industry 4.0 as policy-driven discourse to institutionalize innovation systems in manufacturing, Technol. Forecast. Soc. Change $132 \quad$ (2018) $26 \quad 33$. https://doi.org/10.1016/j.techfore.2018.02.012.

German Federal Ministry, Smart services world - business services, 2017, retrieved from https://www.bmwi.de/Redaktion/EN/Publikationen/smart-service-welt-internetbasiertedienste-fuer-die-wirtschaft.pdf?_blob=publicationFile \&v=7.

H. Bülbül, N. Ömürbek, T. Paksoy, T. Bektaş, An empirical investigation of advanced manufacturing technology investment patterns: evidence from a developing country, J. Eng. Technol. Manag. 30(2) (2013) 136 156. https://doi.org/10.1016/j.jengtecman.2013.01.002.

H. Kagermann, W. Wahlster, J. Helbig, A. Hellinger, M.A.V. Stumpf, L. Treugut, J. Blasco, H. Galloway, U. Findeklee, Securing the future of german manufacturing industry: recommendations for implementing the strategic initiative INDUSTRIE 4.0. Final Report of the Industrie 4.0 Working Group 2013.

H. Moradlou, W. Tate, Reshoring and additive manufacturing, World Rev. Intermodal Transport. Res. 7(3) (2018) 241 263. https://doi.org/10.1504/writr.2018.10014280.

H. Singh, J.S. Khamba, Utilisation of new technologies: a state-of-art-review and future prospective, Int. J. Serv. Oper. Manag. 8(2) (2011) 164 190. https://doi.org/10.1504/ijsom.2011.038571.

H. Small, Visualizing science by citation mapping, J. Am. Soc. Info. Sci. 50(9) (1999) 799813.

H.A. Schildt, J.T. Mattsson, A dense network sub-grouping algorithm for co-citation analysis and its 
implementation in the software tool sitkis, Scientometrics 67(1) (2006) 143163. https://doi.org/10.1556/scient.67.2006.1.9.

H.P. Lu, C.I. Weng, Smart manufacturing technology, market maturity analysis and technology roadmap in the computer and electronic product manufacturing industry, Technol. Forecast. Soc. Change 133 (2018) 85 94. https://doi.org/10.1016/j.techfore.2018.03.005.

H.S. Kang, J.Y. Lee, S. Choi, H. Kim, J.H. Park, J.Y. Son, B.H. Kim, S.D. Noh, Smart manufacturing: past research, present findings, and future directions, Int. J. Precision Eng. Manuf. Green Technol. 3(1) (2016) 111 128. https://doi.org/10.1007/s40684-016-0015-5.

H.W. Chesbrough, Business model innovation: it's not just about technology anymore, Strat. Lead. 35 (2007) 12 17. https://doi.org/10.1108/10878570710833714.

I. Lee, K. Lee, The internet of things (IOT): applications, investments, and challenges for enterprises, Bus. Horiz. 58(4) (2015) 431 440. https://doi.org/10.1016/j.bushor.2015.03.008.

I. Zupic, T. Čater, Bibliometric methods in management and organization, Org. Res. Methods 18(3) (2015) 429 472. https://doi.org/10.1177/1094428114562629.

J. Cenamor, D.R. Sjödin, V. Parida, Adopting a platform approach in servitization: leveraging the value of digitalization, Int. J. Prod. Econ. $192 \quad$ (2017) $54 \quad 65$. https://doi.org/10.1016/j.ijpe.2016.12.033.

J. Holmström, G. Liotta, A. Chaudhuri, Sustainability outcomes through direct digital manufacturingbased operational practices: a design theory approach, J. Clean. Prod. 167 (2018) 951961. https://doi.org/10.1016/j.jclepro.2017.03.092.

J. Holmström, M. Holweg, S.H. Khajavi, J. Partanen, The direct digital manufacturing (r)evolution: definition of a research agenda, Oper. Manag. Res. 9(1-2) (2016) 110. https://doi.org/10.1007/s12063-016-0106-z.

J. Kim, Are countries ready for the new meso revolution? Testing the waters for new industrial change in Korea, Technol. Forecast. Soc. Change $132 \quad$ (2018) $34 \quad 39$. https://doi.org/10.1016/j.techfore.2017.11.006.

J. Lee, B. Bagheri, H.A. Kao, A cyber-physical systems architecture for industry 4.0-based $\begin{array}{lllllll}\text { manufacturing } & \text { systems. } & \text { Manuf. } & \text { Lett. } & 3 & (2015) & 18\end{array}$ https://doi.org/10.1016/j.mfglet.2014.12.001.

J. Lee, H.A. Kao, S. Yang, Service innovation and smart analytics for industry 4.0 and big data environment, Proc. CIRP 16 (2014) 3 8. https://doi.org/10.1016/j.procir.2014.02.001.

J. Nagy, J. Ol, E. Erdei, The role and impact of industry 4.0 and the internet of things on the business strategy of the value chain - the case of Hungary, Sustainability 10 (2018) Article number 3491. https://doi.org/10.3390/su10103491.

J. Ratcliff, D. Metzener, Ratcliff-Obershelp pattern recognition. Dictionary of algorithms and data structures, NIST, 1998.

J.A. Schumpeter, Business cycles: a theoretical and statistical analysis of the capitalist process, McGraw-Hill, New York, NY, 1939.

J.C. Rochet, J. Tirole, Two-sided markets: a progress report, RAND J. Econ. 35 (2006) 645 667. https://doi.org/10.1111/j.1756-2171.2006.tb00036.x

J.E. Rowley, The wisdom hierarchy: representations of the DIKW hierarchy, J. Info. Sci. 33(2) (2007) 
163 180. https://doi.org/10.1177/0165551506070706.

J.M. Müller, D. Kiel, K.I. Voigt, What drives the implementation of industry 4.0? The role of opportunities and challenges in the context of sustainability, Sustainability (Switzerland) 10(1) (2018b) Article number 247. https://doi.org/10.3390/su10010247.

J.M. Müller, O. Buliga, K.I. Voigt, Fortune favors the prepared: how SMEs approach business model innovations in industry 4.0, Technol. Forecast. Soc. Change 132 (2018a) 217. https://doi.org/10.1016/j.techfore.2017.12.019.

J.W. Meyer, B. Rowan, Institutionalized organizations: formal structure as myth and ceremony, Am. J. Soc. 83(2) (1977) 340 363. https://doi.org/10.1086/226550.

K. Ashton, That 'Internet of Things' thing, RFID J. 22(7) (2009) 97114.

K. Ismail, C.R. Isa, L. Mia, Evidence on the usefulness of management accounting systems in integrated manufacturing environment, Pac. Account. Rev. 30(1) (2018a) 219. https://doi.org/10.1108/par-04-2015-0010.

K. Ismail, C.R. Isa, L. Mia, Market competition, lean manufacturing practices and the role of management accounting systems (MAS) information, UKM J. Manag. 52 (2018b) 4761. https://doi.org/10.17576/pengurusan-2018-52-04.

K. Ridgway, C.W. Clegg, D.J. Williams, P. Hourd, M. Robinson, L. Bolton, K. Cichomska, J. Baldwin, The factory of the future, Government Office for Science, Evidence Paper, 29, 2013.

K. Schwab, The fourth industrial revolution, Crown Publishing Group, New York, NY, 2016.

K.K. Boyer, M. Pagell, Measurement issues in empirical research: improving measures of operations strategy and advanced manufacturing technology, J. Oper. Manag. 18(3) (2000) 361374. https://doi.org/10.1016/s0272-6963(99)00029-7.

K.W. Boyack, R. Klavans, Co-citation analysis, bibliographic coupling, and direct citation: which citation approach represents the research front most accurately?, J. Am. Soc. Info. Sci. Technol. 61(12) (2010) 2389 2404. https://doi.org/10.1002/asi.21419.

L. Bibby, B. Dehe, Defining and assessing industry 4.0 maturity levels-case of the defence sector, Prod. Plan. Control 29(12) (2018) 1030 1043. https://doi.org/10.1080/09537287.2018.1503355.

L. Li, China's manufacturing locus in 2025: with a comparison of "Made-in-China 2025" and "Industry 4.0," Technol. Forecast. Soc. Change $135 \quad$ (2018) 6674. https://doi.org/10.1016/j.techfore.2017.05.028.

L. Waltman, A review of the literature on citation impact indicators, J. Info. 10(2) (2016) 365391. https://doi.org/10.1016/j.joi.2016.02.007.

L.A. Borges, K.H. Tan, Incorporating human factors into the AAMT selection: a framework and $\begin{array}{llllllll}\text { process, Int. J. } & \text { Prod. } & \text { Res. } & \text { 55(5) } & \text { (2017) } & 1459 & 1470 .\end{array}$ https://doi.org/10.1080/00207543.2016.1259668.

L.D. Xu, E.L. Xu, L. Li, Industry 4.0: state of the art and future trends, Int. J. Prod. Res. 56(8) (2018) 2941 2962. https://doi.org/10.1080/00207543.2018.1444806.

L.S. Dalenogare, G.B. Benitez, N.F. Ayala, A.G. Frank, The expected contribution of industry 4.0 technologies for industrial performance, Int. J. Prod. Econ. 204 (2018) 383394. https://doi.org/10.1016/j.ijpe.2018.08.019. 
M. Bastian, S. Heymann, M. Jacomy, Gephi: An open source software for exploring and manipulating networks, Icwsm 8 (2009), San Jose, California, 2009, pp. 361-362.

M. Brettel, N. Friederichsen, M. Keller, M. Rosenberg, How virtualization, decentralization and network building change the manufacturing landscape: an industry 4.0 perspective, Int. J. Mech. Ind. Sci. Eng. 8(1) (2014) 3744.

M. Darbanhosseiniamirkhiz, W.K. Wan Ismail, Advanced manufacturing technology adoption in SMEs: an integrative model, J Technol. Manag. Innov. 7(4) (2012) 112120. https://doi.org/10.4067/s0718-27242012000400009.

M. Ghobakhloo, A. Azar, Business excellence via advanced manufacturing technology and lean-agile manufacturing, J. Manuf. Technol. Manag. 29(1) (2018) 2 24. https://doi.org/10.1108/jmtm-032017-0049.

M. Ghobakhloo, A. Azar, M. Fathi, Lean-green manufacturing: the enabling role of information technology resource. Kybernetes, Emerald Publishing Limited, 2018. https://doi.org/10.1108/k09-2017-0343.

M. Ghobakhloo, T.S. Hong, IT investments and business performance improvement: the mediating role of lean manufacturing implementation, Int. J. Prod. Res. 52(18) (2014) 53675384. https://doi.org/10.1080/00207543.2014.906761.

M. Ghobakhloo, The future of manufacturing industry: a strategic roadmap toward industry 4.0, J. Manuf. Technol. Manag. 29(6) (2018) 910 936. https://doi.org/10.1108/jmtm-02-2018-0057.

M. Hermann, T. Pentek, B. Otto, Design principles for industrie 4.0 scenarios, Proceedings of the Annual Hawaii International Conference on System Sciences, Vol. 2016-March 2016. https://doi.org/10.1109/hicss.2016.488.

M. Kans, A. Ingwald, Business model development towards service management 4.0, Proc. CIRP 47 (2016) 489 494. https://doi.org/10.1016/j.procir.2016.03.228.

M. Khorram Niaki, F. Nonino, Additive manufacturing management: a review and future research $\begin{array}{lllllll}\text { agenda, Int. } & \text { J. } & \text { Prod. } & \text { Res. } & 55(5) & \text { (2017) } & 1419\end{array}$ https://doi.org/10.1080/00207543.2016.1229064.

M. Kim, N.C. Suresh, C. Kocabasoglu-Hillmer, An impact of manufacturing flexibility and technological dimensions of manufacturing strategy on improving supply chain responsiveness: business environment perspective, Int. J. Prod. Res. 51(18) (2013) 55975611. https://doi.org/10.1080/00207543.2013.790569.

M. Lewis, P. Åhlström, B. Yalabik, P. Mårtensson, Implementing advanced service technology in the public sector: an exploratory study of the relevance and limitations of insights from private sector manufacturing technology implementation, Prod. Plan. Control 24(10-11) (2013) 916 930. https://doi.org/10.1080/09537287.2012.666901.

M. Li, A.L. Porter, A. Suominen, Insights into relationships between disruptive technology/innovation and emerging technology: a bibliometric perspective, Technol. Forecast. Soc. Change 129 (2018) 285 296. https://doi.org/10.1016/j.techfore.2017.09.032.

M. Martinsuo, T. Luomaranta, Adopting additive manufacturing in SMEs: exploring the challenges and solutions, J. Manuf. Technol. Manag. 29(6) (2018) 937 957. https://doi.org/10.1108/jmtm02-2018-0030.

M. Mura, M. Longo, P. Micheli, D. Bolzani, The evolution of sustainability measurement research, 
Int. J. Manag. Rev. 20(3) (2018) 661 695. https://doi.org/10.1111/ijmr.12179.

M. Piccarozzi, B. Aquilani, C. Gatti, Industry 4.0 in management studies: a systematic literature review, Sustainability (Switzerland) 10(10) (2018) 1 24. https://doi.org/10.3390/su10103821.

M. Potstada, A. Parandian, D.K. Robinson, J. Zybura, An alignment approach for an industry in the making: DIGINOVA and the case of digital fabrication, Technol. Forecast. Soc. Change 102(2016) 182 192. https://doi.org/10.1016/j.techfore.2015.07.020.

M. Rüßmann, M. Lorenz, P. Gerbert, M. Waldner, J. Justus, P. Engel, M. Harnisch, Industry 4.0: the future of productivity and growth in manufacturing industries, Boston Consulting Group. Vol. 9, 2015, Retrieved from https://www.bcg.com/publications/2015/engineered_products_project_business_industry_4_fu ture_productivity_growth_manufacturing_industries.aspx,

M. Skilton, F. Hovsepian, The 4th Industrial revolution: responding to the impact of artificial intelligence on business, Springer International Publishing AG, Cham, 2017.

M. Yang, S. Evans, D. Vladimirova, P. Rana, Value uncaptured perspective for sustainable business model innovation, J. Clean. Prod. $140 \quad$ (2017) $1794 \quad 1804$. https://doi.org/10.1016/j.jclepro.2016.07.102.

M.E. Moore, L. Rothenberg, H. Moser, Contingency factors and reshoring drivers in the textile and apparel industry, J. Manuf. Technol. Manag. 29(6) (2018) 10251041. https://doi.org/10.1108/jmtm-07-2017-0150.

M.E. Porter, J.E. Heppelmann, How smart, connected products are transforming competition, Harv. Bus. Rev. 92(11) (2014) 6488.

M.J. Cobo, A.G. López-Herrera, E. Herrera-Viedma, F. Herrera, SciMAT: a new science mapping analysis software tool, J. Am. Soc. Info. Sci. Technol. 63(8) (2012) 16091630. https://doi.org/10.1002/asi.22688.

M.M. Kessler, Bibliographic coupling between scientific papers, Am. Doc. 14(1) (1963) 1025.

M.M. Mariani, R. Baggio, M. Fuchs, W. Höpken, Business intelligence and big data in hospitality and tourism: a systematic literature review, Int. J. Contemp. Hosp. Manag. 30(12) (2018) 3514 3554. https://doi.org/10.1108/ijchm-07-2017-0461.

N. Liu, A.V. Roth, E. Rabinovich, Antecedents and consequences of combinative competitive capabilities in manufacturing, Int. J. Oper. Prod. Manag. 31(12) (2011) 12501286. https://doi.org/10.1108/01443571111187448.

N.D. Kondratieff, The long waves in economic life, Rev. Econ. Stat. 17(6) (1935) 105115.

O. Persson, R. Danell, J.W. Schneider, How to use bibexcel for various types of bibliometric analysis. Celebrating scholarly communication studies: a festschrift for Olle Persson at his 60th birthday 5, International Society for Scientometrics and Informetrics Leuven, Belgium: 9-24, 2009.

O. Rehse, S. Hoffmann, C. Kosanke, Tapping into the transformative power of service 4.0, The Boston Consulting Group, 2016, retrieved from https://www.bcg.com/capabilities/operations/service-4-0-transforming-customerinteractions.aspx.

P. Barbieri, F. Ciabuschi, L. Fratocchi, M. Vignoli, What do we know about manufacturing reshoring?, J. Glob. Oper. Strat. Sourc. 11(1) (2018) 79 122. https://doi.org/10.1108/jgoss-02- 
2017-0004.

P. Bello, A.R. Kaufmann, J.M. Diaz-de-Cerio, Advanced manufacturing technologies, quality management practices, and manufacturing performance in the Southern Cone of Latin America, Manag. Res. 13(2) (2015) 187 210. https://doi.org/10.1108/mrjiam-03-2015-0580.

P. Buckley, R. Majumdar, The services powerhouse: increasingly vital to world economic growth, Deloitte Insights 2018, retrieved from https://www2.deloitte.com/ insights/us/en/economy/issues-by-the-numbers/trade-in-services-economy-growth.html.

P. Mongeon, A. Paul-Hus, The journal coverage of web of science and scopus: a comparative analysis, Scientometrics 106(1) (2016) 213 228. https://doi.org/10.1007/s11192-015-1765-5.

P. Schneider, Managerial challenges of industry 4.0: an empirically backed research agenda for a nascent field, Rev. Manag. Sci. 12(3) (2018) 803 848. https://doi.org/10.1007/s11846-018-02832.

P. Spieth, D. Schneckenberg, J.E. Ricart, Business model innovation-state of the art and future challenges for the field, R\&D Manag. 44(3) (2014) $237 \quad 247$. https://doi.org/10.1111/radm.12071.

P.J. DiMaggio, W.W. Powell, The iron cage revisited: institutional isomorphism and collective rationality in organizational fields, Am. Soc. Rev. 48(2) (1983) $147 \quad 160$. https://doi.org/10.2307/2095101.

R. Amit, C. Zott, Creating value through business model innovation, MIT Sloan Manag. Rev. 53(3) (2012) 4149.

R. Amit, C. Zott, Value creation in e-business, Strat. Manag. J. 22(6-7) (2001) 493520. https://doi.org/10.1002/smj.187.

R. Drath, A. Horch, Industrie 4.0: hit or hype? [Industry Forum], IEEE Ind. Elec. Mag. 8(2) (2014) 56 58. https://doi.org/10.1109/mie.2014.2312079.

R. Geissbauer, J. Vedso, S. Schrauf, Industry 4.0: building the digital enterprise, 2016, retrieved from https://www.pwc.com/gx/en/industries/industries-4.0/landing-page/industry-4.0-building-yourdigital-enterprise-april-2016.pdf.

R. Jiang, R. Kleer, F.T. Piller, Predicting the future of additive manufacturing: a Delphi study on economic and societal implications of 3D printing for 2030, Technol. Forecast. Soc. Change 117 (2017) 84 97. https://doi.org/10.1016/j.techfore.2017.01.006.

R. Mishra, A.K. Pundir, L. Ganapathy, Empirical assessment of factors influencing potential of manufacturing flexibility in organization, Bus. Proc. Manag. J. 24(1) (2018) 158182. https://doi.org/10.1108/bpmj-07-2016-0157.

R. Vogel, W.H. Güttel, The dynamic capability view in strategic management: a bibliometric review, Int. J. Manag. Rev. 15(4) (2013) 426 446. https://doi.org/10.1111/ijmr.12000.

R.F. Lusch, S.L. Vargo, G. Wessels, Toward a conceptual foundation for service science: contributions from service-dominant logic, IBM Syst. J. 47 (1) (2008) 514. https://doi.org/10.1147/sj.471.0005.

R.F. Lusch, S.L. Vargo, Service-dominant logic: premises, perspectives, possibilities, Cambridge University Press, UK, 2014. https://doi.org/10.1017/cbo9781139043120.002.

R.U. Ayres, Technological transformations and long waves: part I, Technol. Forecast. Soc. Change 37(1) (1990) 137. 
R.Y. Zhong, G.Q. Huang, S. Lan, Q.Y. Dai, X. Chen, T. Zhang, A big data approach for logistics trajectory discovery from RFID-enabled production data, Int. J. Prod. Econ. 165 (2015) 260272. https://doi.org/10.1016/j.ijpe.2015.02.014.

S. Chekurov, S. Metsä-Kortelainen, M. Salmi, I. Roda, A. Jussila, The perceived value of additively manufactured digital spare parts in industry: an empirical investigation, Int. J. Prod. Econ. 205 (2018) 87 97. https://doi.org/10.1016/j.ijpe.2018.09.008.

S. Ford, M. Despeisse, Additive manufacturing and sustainability: an exploratory study of the advantages and challenges, J. Clean. Prod. $137 \quad(2016) \quad 1573 \quad 1587$. https://doi.org/10.1016/j.jclepro.2016.04.150.

S. Goyal, S. Grover, A fuzzy multi attribute decision making approach for evaluating effectiveness of advanced manufacturing technology-in Indian context, Int. J. Prod. Qual. Manag. 11(2) (2013) 150 178. https://doi.org/10.1504/ijpqm.2013.052022.

S. Nambisan, Digital entrepreneurship: toward a digital technology perspective of entrepreneurship, Entrepreneurship Theory Practice 41(6) (2017) 1029 1055. https://doi.org/10.1111/etap.12254.

S. Nambisan, S. Zahra, Y. Luo, Global platforms and ecosystems: implications for international business theories, J. Int. Bus. Stud. (2019) forthcoming. https://doi.org/10.1057/s41267-01900262-4.

S. Saberi, R.M. Yusuff, Exploratory study into advanced manufacturing technology (amt) usage in Malaysian small- and medium-sized enterprises (SMEs), Int. J. Innov. Technol. Manag. 9(2) (2012) Article number 12500150. https://doi.org/10.1142/s0219877012500150.

S. Vandermerwe, J. Rada, Servitization of business: adding value by adding services, Eur. Manag. J. 6(4) (1988) 314 324. https://doi.org/10.1016/0263-2373(88)90033-3.

S.L. Vargo, R.F. Lusch, Evolving to a new dominant logic for marketing, J. Market. 68(1) (2004) 1 17. https://doi.org/10.1509/jmkg.68.1.1.24036.

S.L. Vargo, R.F. Lusch, Institutions and axioms: an extension and update of service-dominant logic, J. Acad. Market. Sci. 44(1) (2016) 5 23. https://doi.org/10.1007/s11747-015-0456-3.

S.L. Vargo, R.F. Lusch, Service-dominant logic: continuing the evolution, J. Acad. Market. Sci. 36(1) (2008) 110.

T. Baines, H. Lightfoot, P. Smart, S. Fletcher, Servitization of manufacture: Exploring the deployment and skills of people critical to the delivery of advanced services, J. Manuf. Technol. Manag, 24(4) (2013) 637 646. https://doi.org/10.1108/17410381311327431.

T. Eisenmann, G. Parker, M. Van Alstyne, Platform envelopment, Strat. Manag. J. 32(12) (2011) 1270 1285. https://doi.org/10.1002/smj.935.

T. Rayna, L. Striukova, From rapid prototyping to home fabrication: how 3D printing is changing business model innovation, Technol. Forecast. Soc. Change 102 (2016) 214224. https://doi.org/10.1016/j.techfore.2015.07.023.

T.D. Oesterreich, F. Teuteberg, Understanding the implications of digitisation and automation in the context of industry 4.0: a triangulation approach and elements of a research agenda for the $\begin{array}{lllll}\text { construction } & \text { industry, Comp. } & \text { Ind. } 83 & \text { (2016) } & 121\end{array}$ https://doi.org/10.1016/j.compind.2016.09.006. 
T.K. Sung, Industry 4.0: a Korea perspective, Technol. Forecast. Soc. Change 132 (2018) 4045. https://doi.org/10.1016/j.techfore.2017.11.005.

T.V. Scannell, S.A. Melnyk, R.J. Calantone, Shop floor manufacturing technology adoption: an adaptation of the technology acceptance model, Int. J. Manuf. Technol. Manag. 23(3-4) (2011) 193 213. https://doi.org/10.1504/ijmtm.2011.045516.

V. Roblek, M. Meško, A, Krapež. A complex view of industry 4.0. Sage Open 6(2) (2016). https://doi.org/10.1177/2158244016653987.

V.D. Blondel, J.L. Guillaume, R. Lambiotte, E. Lefebvre, Fast unfolding of communities in large networks, J. Stat. Mech. 10 (2008) 100 108. https://doi.org/10.1088/1742-5468/2008/10/p10008.

V.I. Levenshtein, Binary codes capable of correcting deletions, insertions, and reversals, In Soviet Physics Doklady 10 (1966) 707710.

W. Glänzel, B. Thijs, Using 'Core Documents' for detecting and labelling new emerging topics, Scientometrics 91(2) (2011) 399 416. https://doi.org/10.1007/s11192-011-0591-7.

W.H. Tsai, S.Y. Lai, Green production planning and control model with ABC under industry 4.0 for the paper industry, Sustainability (Switzerland) 10(8) (2018) Article number 2932. https://doi.org/10.3390/su10082932.

W.H. Tsai, Y.H. Lu, A framework of production planning and control with carbon tax under industry 4.0, Sustainability (Switzerland) 10(9) (2018) Article number 3221. https://doi.org/10.3390/su10093221.

X. Liu, W. Glänzel, B. De Moor, Optimal and hierarchical clustering of large-scale hybrid networks for scientific mapping, Scientometrics 91(2) (2012) 473 493. https://doi.org/10.1007/s11192011-0600-x.

X. Wang, S.K. Ong, A.Y.C. Nee, A comprehensive survey of ubiquitous manufacturing research, Int. J. Prod. Res. 56(1-2) (2018) 604 628. https://doi.org/10.1080/00207543.2017.1413259.

Y. Cheng, R. Matthiesen, S. Farooq, J. Johansen, H. Hu, L. Ma, The evolution of investment patterns on Advanced Manufacturing Technology (AMT) in manufacturing operations: a longitudinal analysis, Int. J. Prod. Econ. 203 (2018) 239 253. https://doi.org/10.1016/j.ijpe.2018.06.019.

Y. Li, G. Jia, Y. Cheng, Y. Hu, Additive manufacturing technology in spare parts supply chain: a comparative study, Int. J. Prod. Res. 55(5) (2017) $1498 \quad 1515$. https://doi.org/10.1080/00207543.2016.1231433.

Y. Liao, F. Deschamps, E. Loures, F.R. de L.F.P. Ramos, Past, present and future of industry 4.0 - a systematic literature review and research agenda proposal, Int. J. Prod. Res. 55(12) (2017) 3609 3629. https://doi.org/10.1080/00207543.2017.1308576.

Y. Lu, Industry 4.0: a survey on technologies, applications and open research issues, J. Ind. Info. Integr. 6 (2017) 110.

Z. Ma, D. Liang, K.H. Yu, Y. Lee, Most cited business ethics publications: mapping the intellectual structure of business ethics studies in 2001-2008, Bus. Ethics 21(3) (2012) 286297. https://doi.org/10.1111/j.1467-8608.2012.01652.x. 


\section{Appendix}

Table 9

Most cited papers among the retrieved documents

\begin{tabular}{|c|c|c|c|c|c|}
\hline Cited & Authors & Year & Document Title & $\begin{array}{l}\text { Type of } \\
\text { Document }\end{array}$ & Journal Title \\
\hline 43 & $\begin{array}{l}\text { Kagermann, H., Wahlster, } \\
\text { and W., Helbig, J., }\end{array}$ & 2013 & $\begin{array}{l}\text { Recommendations For Implementing The Strategic } \\
\text { Initiative Industrie 4.0: Final Report Of The Industrie } 4.0 \\
\text { Working Group }\end{array}$ & Report & \\
\hline 33 & $\begin{array}{l}\text { Lee, J., Bagheri, B., and } \\
\text { Kao, H.A., }\end{array}$ & 2015 & $\begin{array}{l}\text { A Cyber-Physical Systems Architecture For Industry } \\
\text { 4.0-Based Manufacturing Systems }\end{array}$ & Article & Manufacturing Letters \\
\hline 31 & $\begin{array}{l}\text { Hermann, M., Pentek, T., } \\
\text { andOtto, B., }\end{array}$ & 2016 & Design Principles For Industrie 4.0 Scenarios & $\begin{array}{l}\text { Conference } \\
\text { Paper }\end{array}$ & $\begin{array}{l}\text { 49Th Hawaii International } \\
\text { Conference On System } \\
\text { Sciences (Hicss) }\end{array}$ \\
\hline 30 & $\begin{array}{l}\text { Lee, J., Kao, H.-A., and } \\
\text { Yang, S., }\end{array}$ & 2014 & $\begin{array}{l}\text { Service Innovation And Smart Analytics For Industry } \\
\text { 4.0 And Big Data Environment }\end{array}$ & $\begin{array}{l}\text { Conference } \\
\text { paper }\end{array}$ & Procedia Cirp \\
\hline 24 & $\begin{array}{l}\text { Lasi, H., Fettke, P., Kemper, } \\
\text { H.G., Feld, T., Hoffmann, } \\
\text { M., }\end{array}$ & 2014 & Industry 4.0 & Article & $\begin{array}{l}\text { Business \& Information } \\
\text { Systems Engineering }\end{array}$ \\
\hline 24 & Porter, M., Heppelmann, J., & 2014 & $\begin{array}{l}\text { How Smart, Connected Products Are Transforming } \\
\text { Competition }\end{array}$ & Note & Harvard Business Review \\
\hline 22 & Yin, R.K., & 2014 & Case Study Research Design And Methods & Book & \\
\hline 21 & Kotha, S., Swamidass, P.M., & 2000 & $\begin{array}{l}\text { Strategy, Advanced Manufacturing Technology And } \\
\text { Performance: Empirical Evidence From Us } \\
\text { Manufacturing Firms }\end{array}$ & Article & $\begin{array}{l}\text { Journal Of Operations } \\
\text { Management }\end{array}$ \\
\hline 21 & Fornell, C., Larcker, D.F., & 1981 & $\begin{array}{l}\text { Structural Equation Models With Unobservable } \\
\text { Variables And Measurement Error: Algebra And } \\
\text { Statistics }\end{array}$ & Article & $\begin{array}{l}\text { Journal Of Marketing } \\
\text { Research }\end{array}$ \\
\hline 20 & Barney, J.B., & 1991 & Firm Resources And Sustained Competitive Advantage & Article & Journal Of Management \\
\hline 18 & Stock, T., Seliger, G., & 2016 & $\begin{array}{l}\text { Opportunities Of Sustainable Manufacturing In Industry } \\
4.0\end{array}$ & $\begin{array}{l}\text { Conference } \\
\text { Paper }\end{array}$ & Procedia Cirp \\
\hline 16 & $\begin{array}{l}\text { Brettel, M., Friederichsen, } \\
\text { N., Keller, M., Rosenberg, } \\
\text { M., }\end{array}$ & 2014 & $\begin{array}{l}\text { How Virtualization, Decentralization And Network } \\
\text { Building Change The Manufacturing Landscape: An } \\
\text { Industry 4.0 Perspective }\end{array}$ & Article & $\begin{array}{l}\text { International Journal of } \\
\text { Information and }\end{array}$ \\
\hline
\end{tabular}




\begin{tabular}{|c|c|c|c|c|c|}
\hline & & & & & $\begin{array}{l}\text { Communication } \\
\text { Engineering }\end{array}$ \\
\hline 15 & $\begin{array}{l}\text { Wang, S., Wan, J., Li, D., } \\
\text { Zhang, C., }\end{array}$ & 2016 & $\begin{array}{l}\text { Implementing Smart Factory Of Industrie 4.0: An } \\
\text { Outlook () Int. J. Distrib. Sens. Netw., }\end{array}$ & Article & $\begin{array}{l}\text { International Journal of } \\
\text { Distributed Sensor } \\
\text { Networks }\end{array}$ \\
\hline 15 & $\begin{array}{l}\text { Kang, H.S., Lee, J.Y., Choi, } \\
\text { S., Kim, H., Park, J.H., Son, } \\
\text { J.Y., Do Noh, S., }\end{array}$ & 2016 & $\begin{array}{l}\text { Smart Manufacturing: Past Research, Present Findings, } \\
\text { And Future Directions }\end{array}$ & Article & $\begin{array}{l}\text { International Journal of } \\
\text { Precision Engineering and } \\
\text { Manufacturing-Green } \\
\text { Technology }\end{array}$ \\
\hline 14 & $\begin{array}{l}\text { Ivanov, D., Dolgui, A., } \\
\text { Sokolov, B., Werner, F., } \\
\text { Ivanova, M., }\end{array}$ & 2016 & $\begin{array}{l}\text { A Dynamic Model And An Algorithm For Short-Term } \\
\text { Supply Chain Scheduling In The Smart Factory Industry } \\
4.0\end{array}$ & Article & $\begin{array}{l}\text { International Journal of } \\
\text { Production Research }\end{array}$ \\
\hline 14 & Berman, B., & 2012 & 3-D Printing: The New Industrial Revolution & Article & Business horizons \\
\hline 13 & Eisenhardt, K.M., & 1989 & Building Theories From Case Study Research & Article & $\begin{array}{l}\text { Academy of Management } \\
\text { Review }\end{array}$ \\
\hline 13 & $\begin{array}{l}\text { Podsakoff, P.M., } \\
\text { Mackenzie, S.B., Lee, J.Y., } \\
\text { Podsakoff, N.P., }\end{array}$ & 2003 & $\begin{array}{l}\text { Common Method Biases In Behavioral Research: A } \\
\text { Critical Review Of The Literature And Recommended } \\
\text { Remedies }\end{array}$ & Article & $\begin{array}{l}\text { Journal Of Applied } \\
\text { Psychology }\end{array}$ \\
\hline 13 & $\begin{array}{l}\text { Atzori, L., Iera, A., } \\
\text { Morabito, G., }\end{array}$ & 2010 & The Internet Of Things: A Survey & Article & Computer Networks \\
\hline 13 & Kagermann, H., & 2015 & $\begin{array}{l}\text { Change Through Digitization-Value Creation In The } \\
\text { Age Of Industry } 4.0\end{array}$ & Book & \\
\hline
\end{tabular}

